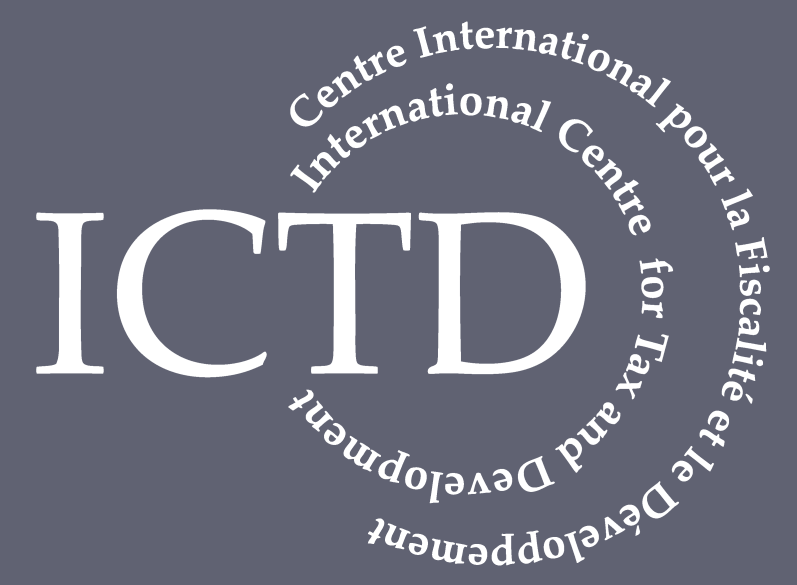

Working Paper 76

Forest Tlaxation and REDD+: An Analysis of Potential Impacts in Cameroon, Ghana and Sierra Leone

Stephen Spratt, Philip Kargbo, Emmanuel Marfo, Emmanuel Ngungoh and Sabaheta Ramcilovik-Suominen

March 2018

BILL \& MELINDA

GATES foundation 


\section{ICTD Working Paper 76}

\section{Forest Taxation and REDD+: An Analysis of Potential Impacts in Cameroon, Ghana and Sierra Leone}

Stephen Spratt, Philip Kargbo, Emmanuel Marfo, Emmanuel Ngungoh and Sabaheta Ramcilovik-Suominen

March 2018 
Forest Taxation and REDD+: An Analysis of Potential Impacts in Cameroon, Ghana and Sierra Leone Stephen Spratt, Philip Kargbo, Emmanuel Marfo, Emmanuel Ngungoh and Sabaheta Ramcilovik-Suominen ICTD Working Paper 76

First published by the Institute of Development Studies in March 2018

(C) Institute of Development Studies 2018

ISBN: 978-1-78118-433-2

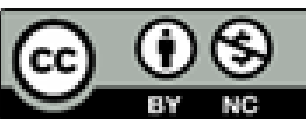

This is an Open Access paper distributed under the terms of the Creative Commons Attribution Non Commercial 4.0 International license, which permits downloading and sharing provided the original authors and source are credited - but the work is not used for commercial purposes. http://creativecommons.org/licenses/by-nc/4.0/legalcode

Available from:

The International Centre for Tax and Development at the Institute of Development Studies, Brighton BN1 9RE, UK

Tel: +44 (0) 127360626

Email: info@ictd.ac.uk

Web: www.ictd/en/publications

IDS is a charitable company limited by guarantee and registered in England

Charity Registration Number 306371

Charitable Company Number 877338 


\title{
Forest Taxation and REDD+: An Analysis of Potential Impacts in Cameroon, Ghana and Sierra Leone
}

\author{
Stephen Spratt, Philip Kargbo, Emmanuel Marfo, Emmanuel Ngungoh and \\ Sabaheta Ramcilovik-Suominen
}

\section{Summary}

This research explores the impacts that REDD+ could have on forest tax systems in three countries in sub-Saharan Africa, and considers how policy could be designed to increase the chances that these impacts are positive. To assess this, a methodological framework is identified and adapted. The framework has been used to explore how the implementation of a new policy regime affects the interests and thus behaviours of actors in related, existing regimes. The implementation of REDD+ in relation to forest tax systems seems well suited to such an approach.

The countries concerned are Cameroon, Ghana and Sierra Leone. While they are at different stages of the process, a common finding is that long-term impacts will depend on the detail of REDD+ design and implementation, and that many of the most important decisions have yet to be taken. Domestically, the key outstanding questions are: the extent of stakeholder participation in the design and implementation of programmes; how equitably financial benefits are distributed; whether REDD+ coverage is restricted to forest areas that are already protected, or extended to areas currently used for commercial forestry; how monitoring, reporting and verification (MRV) is implemented and whether this overlaps with forestry reporting practices; whether REDD+ is implemented nationally or locally; and whether existing or new channels are used.

As well as these domestic policy choices, three international aspects of REDD+ that will have a strong influence on its long-term impacts have not been settled. First, there is the question of whether and how REDD+ finance will come with governance conditions; second, what will the total level of REDD+ financing ultimately be, and how will this be allocated between countries; and finally, a crucial factor in determining the impact on the forestry sector will be the value of REDD+ per unit of carbon. Depending on how these questions are answered in practice, a number of scenarios could develop, and this paper identifies those where the impact of REDD+ on forest tax objectives are most likely to be positive.

We therefore have a window of opportunity. The implementation of REDD+ has the potential to trigger positive change with respect to forest governance and taxation, but only if it is designed and implemented with care. What is needed is the political will to deliver this, internationally and nationally, and the financial resources to back this up.

Keywords: REDD+; climate change; rainforests; forest taxation; forest governance; benefit sharing; competing rights; logging; forest peoples.

Stephen Spratt is a Research Fellow at IDS. Stephen's research interests relate to development and green finance and low carbon development. Professionally, he has been Head of the Sustainable Markets Group at IIED, Chief Economist at the New Economics Foundation, and a lecturer in international finance and development at the University of Reading. He has also worked in the private sector in the City of London.

Philip Kargbo is Director of the Monitoring, Research and Planning Department of the National Revenue Authority, Sierra Leone. He is also an experienced researcher in 
economics; public sector revenue mobilisation, analysis and forecasting; social policy impact analysis; and development policy.

Emmanuel Ngungoh is the Coordinator of the African Development Association (ADAS), a research and consultancy organisation on governance and sustainable development in Cameroon and the COMIFAC Central African Sub Region. Previously Emmanuel was a Director at British Council Cameroon, coordinating projects and programmes, including climate change collaborative research and higher education links among UK and Cameroonian universities.

Emmanuel Marfo is a principal research scientist with the Council for Scientific and Industrial Research, Forestry Research Institute of Ghana. He is a policy scientist and has mainly studied and published in the area of forest conflict and governance and policy impacts. He is an elected Member of Parliament of the Oforikrom Constituency, Kumasi, Ghana.

Sabaheta Ramcilovik-Suominen is a postdoctoral researcher at the Faculty of Social Sciences and Business Administration, University of Eastern Finland. She works on environmental, social and political aspects of forest and land use changes in the Global South. She focuses on: (i) global environmental interventions and the resulting policy and institutional change, (ii) power relations between actors, sectors and levels of administration; and (iii) forest-based livelihoods and access and rights to resources. Forest law compliance and the concepts of informal forest activities - both legal and illegal - is an additional issue that she has extensively worked on, especially in Ghana. Her current postdoctoral research looks at socio-political implications of the EU's FLEGT (Forest Law Enforcement, Governance and Trade) and REDD+ (Reduced Emissions from Deforestation and Forest Degradation) in Laos. 


\section{Contents}

Summary 3

$\begin{array}{ll}\text { Acknowledgements } & 7\end{array}$

$\begin{array}{ll}\text { Acronyms } & 7\end{array}$

$\begin{array}{ll}\text { Introduction } & 9\end{array}$

$1 \quad$ Research questions and case study choice 10

2 Framework for analysis of interactions between REDD+ and forest tax systems

2.1 Causal mechanisms for institutional interactions 11

2.1.1 Cognitive interaction as a causal mechanism 12

2.1.2 Behavioural interaction as a causal mechanism 13

2.1.3 Impact-level interactions as causal mechanisms 13

$\begin{array}{lll}2.2 & \text { Objectives of forest tax systems and REDD+ }\end{array}$

$3 \quad$ Case study country backgrounds $\quad 14$

3.1 Cameroon 14

3.2 Ghana 16

$\begin{array}{lll}3.3 & \text { Sierra Leone } & 18\end{array}$

$4 \quad$ Analysis of regime interaction and policy options in

case study countries $\quad 21$

$\begin{array}{lll}4.1 & \text { REDD+ scenarios } & 21\end{array}$

4.1.1 REDD+ scenarios and global factors $\quad 21$

4.1.2 REDD+ scenarios and domestic factors 23

4.2 Forms of REDD+ consequences in three countries 25

4.3 Behavioural impacts under different scenarios 28

$\begin{array}{ll}\text { 4.3.1 Cameroon } & 28\end{array}$

4.3.2 Ghana $\quad 32$

4.3.3 Sierra Leone $\quad 34$

4.4 From behaviours to forest tax outcomes 37

$\begin{array}{ll}\text { 4.4.1 Central government stakeholders } & 37\end{array}$

4.4.2 Local stakeholders 39

4.4.3 Private sector stakeholders $\quad 40$

4.4.4 Donors, NGOs and CSOs 42

4.5 REDD+ scenarios, forest tax outcomes and policy options
in each country

4.5.1 REDD+ scenarios and forest tax outcomes 43

4.5.2 Current policy debates in Cameroon, Ghana and Sierra Leone $\quad 45$

$5 \quad$ Concluding remarks $\quad 51$

$\begin{array}{ll}\text { References } & 52\end{array}$

Tables

Table $1 \quad$ Ghana's forest tax revenues, $2005 \quad 18$

Table $2 \quad$ REDD+ implementation scenarios 21

$\begin{array}{ll}\text { Table } 3 & \text { Current and anticipated governance and economic impacts of } \\ & \text { REDD+ implementation }\end{array}$

Table $4 \quad$ Stakeholder impacts in Cameroon under global scenarios 29 
Table $5 \quad$ Stakeholder impacts in Cameroon under domestic scenarios 30

Table $6 \quad$ Stakeholder impacts in Ghana under global scenarios 32

Table $7 \quad$ Stakeholder impacts in Ghana under domestic scenarios 33

Table $8 \quad$ Stakeholder impacts in Sierra Leone under global scenarios 34

Table $9 \quad$ Stakeholder impacts in Sierra Leone under domestic scenarios 36

Table $10 \quad$ Forest tax objectives/outcomes and central stakeholder behaviours 38

Table 11 Forest tax objectives/outcomes and local stakeholder behaviours 39

$\begin{array}{lll}\text { Table } 12 & \begin{array}{l}\text { Forest tax objectives/outcomes and private sector } \\ \text { stakeholder behaviours }\end{array}\end{array}$

$\begin{array}{ll}\text { Table } 13 & \begin{array}{l}\text { Forest tax objectives/outcomes and donor and NGO } \\ \text { stakeholder behaviours }\end{array}\end{array}$

Table $14 \quad$ Potential impact of REDD+ scenarios on forest tax outcomes 43 


\section{Acknowledgements}

We would like to thank the ICTD for funding this research.

\section{Acronyms}

\begin{tabular}{|c|c|}
\hline CCPM & $\begin{array}{l}\text { Consultation Circle of Partners of the Ministry of Environment, Nature } \\
\text { Protection and Sustainable Development (MINEPDED) and the Ministry of } \\
\text { Forestry and Wildlife (MINFOF). Cameroon }\end{array}$ \\
\hline CIFOR & Centre for International Forestry Research \\
\hline CIME & Taxation Centre for Medium-sized Enterprises, Cameroon \\
\hline CSO & Civil society organisation \\
\hline CSR & Corporate social responsibility \\
\hline DAs & District assemblies \\
\hline DGI & Direction Générale des Impots - tax agency, Cameroon \\
\hline DOLTA & Domestic Lumber Trade Association of Ghana \\
\hline EPA & Environmental Protection Agency, Ghana and Sierra Leone \\
\hline EU & European Union \\
\hline FC & Forestry Commission \\
\hline & Forestry Division, Sierra Leone \\
\hline FEICOM & Special Equipment and Intercommunal Intervention Fund, Cameroon \\
\hline FSD & Forest Service Division, Forestry Commission, Ghana \\
\hline GHG & Greenhouse gas \\
\hline GTMO & Ghana Timber Millers' Organization \\
\hline $\mathrm{Ha}$ & Hectares \\
\hline IFAs & Illegal forest activities \\
\hline IRAD & Institute of Agricultural Research for Development, Cameroon \\
\hline IUCN & International Union for Conservation of Nature \\
\hline MAFFS & Ministry of Agriculture, Forestry and Food Security, Sierra Leone \\
\hline MESTI & Ministry of Environment, Science, Technology and Innovation, Ghana \\
\hline MINADER & Ministry of Agriculture and Rural Development, Cameroon \\
\hline MINAS & Ministry for Social Affairs, Cameroon \\
\hline MINATD & Ministry of Territorial Administration and Decentralisation, Cameroon \\
\hline MINEE & Ministry of Energy and Water Resources, Cameroon \\
\hline MINEPDED & $\begin{array}{l}\text { Ministry of Environment, Nature Protection and Sustainable Development, } \\
\text { Cameroon }\end{array}$ \\
\hline MINFI & Ministry of Finance, Cameroon \\
\hline MINFOF & Ministry of Forestry and Wildlife, Cameroon \\
\hline MLNR & Ministry of Lands and Natural Resources, Ghana \\
\hline MOFED & Ministry of Finance and Economic Development, Sierra Leone \\
\hline MOFEP & Ministry of Finance and Economic Planning, Ghana \\
\hline MRV & Monitoring, reporting and verification \\
\hline NCCS & National Climate Change Secretariat, Sierra Leone \\
\hline NPAA & National Protected Area Authority, Sierra Leone \\
\hline NRA & National Revenue Authority, Sierra Leone \\
\hline NRSC & National REDD+ Steering Committee, Ghana \\
\hline NWFPs & Timber and non-wood forest products \\
\hline ONACC & National Observatory on Climate Change, Cameroon \\
\hline
\end{tabular}


PSRF Forest Revenue Security Programme (Programme de Sécurisation des Recettes Forestières), Cameroon

REDD+ $\quad$ Reducing Emissions from Deforestation and Degradation

RFA

SFM Annual Forest Royalty (Redevance Forestière Annuelle), Cameroon

TIDD Sustainable forest management

TNC

Timber Industry Development Division, Ghana Forestry Commission

TS Transnational corporation Technical Secretariat, MINEPDED, Cameroon 


\section{Introduction}

A third of the Earth's surface is covered by forests. Forests provide a huge range of benefits and services. As well as timber for fuel and construction, they provide for the subsistence needs of around 1.2 billion people, and generate up to a quarter of household income for families living in or near forests globally (FAO 2004; Seymour 2011). Forests also provide habitats for flora and fauna and a variety of timber and non-wood forest products (NWFPs) for consumption, medicinal use and sale.

As well as providing 'amenity services' in terms of recreation (Gupta 2012), forests provide a range of ecosystem services, including watershed protection and the atmospheric regulation of $\mathrm{CO}_{2}$ (De Groot, Wilson and Boumans 2002). Globally, forests hold up to 250 metric tons of stored carbon per hectare (Lopez and Galinato 2005), and forest clearance is a major source of carbon emissions, accounting for around 17 per cent of annual greenhouse gas emissions (GHGs) (IPCC 2007).

Deforestation has reduced forest cover by 40 million hectares (ha) since 2000 (Gupta 2012). A combination of population growth and the need for economic development means forests compete for space with what are often seen as more pressing, and certainly more profitable, land uses (Gupta 2012; Fuller 2006).

As well as being a vital global resource, forests are also a key source of local economic, social and environmental benefits in developing countries. For the most forested countries, particularly in tropical regions, forests may be the most valuable resource they own. The extent to which this value should be extracted, and how this value should be distributed, are thus crucial development questions.

How forests are governed and taxed is central to these questions. Forest taxation systems are designed to generate public revenues but may also have other objectives such as ensuring forests are managed sustainably over time, or that the domestic timber industry can expand and create more value added. This is not just about taxation, of course. Forests are often seen by indigenous communities as integral to their culture and way of life, while NGOs may see pristine forests as priceless homes of biodiversity. Concession holders, in contrast, see the same land as a source of revenue.

The record is not good. In most low- and middle-income countries, revenues from forest taxation are far lower than would be expected given rates of deforestation. At the same time, illegal forest activities (IFAs) are rife. Despite decades of analysis and reform, the forestry sector remains inextricably linked to corruption and poor governance in many countries, with the interests of indigenous peoples receiving little, if any, attention.

The Reducing Emissions from Deforestation and Degradation (REDD+) process is just beginning to encroach into these complex systems of incentives, governance arrangements and power relations. As the name suggests, REDD+ (and its associated initiatives) is designed to reduce or prevent deforestation, safeguarding forests' role as global carbon sinks. As REDD+ increases in scale and reach, its impacts on the economics and governance of forests will increase. This will influence the ability of different stakeholders to achieve their objectives, including with respect to forest taxation.

The research summarised in this paper was designed to explore these potential impacts, with three principal aims. First, to map the channels of impact and interaction between REDD+ and forest tax governance systems. Second, to assess the nature and scale of potential impacts, and the determinants of each. And third, to identify policy options to 
increase the likelihood that REDD+ implementation will lead to positive change in forest tax governance systems.

The paper is organised into four sections. Parts 1 and 2 describe the research questions, conceptual framework and methodology. Part 3 gives some background on the case study countries: Cameroon, Ghana, and Sierra Leone. Part 4 applies the conceptual framework and presents the results of this process.

\section{Research questions and case study choice}

The three questions that guided the research are:

(i) How will the implementation of REDD+ affect the governance of different forest tax systems in sub-Saharan Africa, and how can the effectiveness of these systems be enhanced?

(ii) How will the implementation of REDD+ affect the economics of forest taxation in subSaharan Africa, and how can tax design be improved in the light of this?

(iii) In the context of different forest tax regimes, how should REDD+ programmes be designed and implemented to best achieve their goals in a complementary way?

The research took place in three countries: Cameroon, Ghana and Sierra Leone. The countries chosen have enough in common to enable comparison: i.e. they are all in subSaharan Africa's tropical zone with natural rainforests; have experienced rapid and extensive deforestation (to varying degrees) and illegal forest activities; and have well developed systems of forest taxation in place. There are also significant differences with respect to:

a. Background conditions: e.g. Sierra Leone and Ghana are Anglophone, while Cameroon is a Francophone country. ${ }^{1}$ Sierra Leone is a post-conflict, least developed country (LDC), while Cameroon and Ghana are relatively stable lower-middle-income countries.

b. Approach to forest taxation: e.g. while the approach is quite centralised in all three countries, they also have different decentralised elements. Cameroon and Ghana use auctions to allocate concessions, for example, while an administrative approach is used in Sierra Leone.

c. REDD+ progress: e.g. Cameroon and Ghana are both REDD+ Partner Countries, but Sierra Leone is a fairly recent entrant to the REDD+ system, with its national REDD+ 'readiness' capacity building and pilot development programme being launched in 2013. The process is now at its commencement stage.

The application of a comparative approach is thus designed to explore the impact of these different elements on the research questions.

\footnotetext{
There is a large literature on the impact of colonialism on development trajectories and outcomes in Africa. In a seminal article in the Journal of Political Economy, for example, La Porta, Lopez-de-Silanes, Shleifer, and Vishny (1998) demonstrate different levels of financial sector development between Francophone and Anglophone countries, ascribing this to the impact of English Common Law versus the French Civil Code. In an American Economic Review article of 2001, Acemoglu and Robinson examine the colonial impact on economic development more broadly, focusing on the role of institutions. In a study presented at the 2011 Annual Meeting of the American Political Studies Association, Lee and Schultz compare the impact of British and French colonial rule in different parts of the same country: Cameroon. Specifically on the issue of taxation, Mkandawire (2010) explores the relationship between tax effort and colonial legacy in Africa in an Institute for Futures Studies working paper, also published in the Journal of Development Studies. There are many other examples of this type of research which could be referenced, suggesting that the hypothesis that colonial legacies may have some impact on countries' approach to forest taxation is worth exploring further.
} 


\section{Framework for analysis of interactions between REDD+ and forest tax systems}

How might the introduction of REDD+ affect outcomes in forest tax systems? This section describes the framework that has been used to address this question in Cameroon, Ghana and Sierra Leone. The framework adapts and extends that developed by Gehring and Oberthür (2009), which was developed to explore the 'causal' interactions between international institutions or 'regimes'. ${ }^{2}$

Three important differences should be noted. First, we are not examining the interaction between two international institutions (or regimes). Rather, we are exploring how the implementation of one such institution (REDD+) interacts with, and affects the outcomes of, an existing domestic institution (forest tax systems). A second difference is that these interactions and effects cannot be tested empirically, as they have not yet occurred, or are only just beginning. What we can do, however, is identify the channels through which REDD+ could affect outcomes in forest tax systems, and examine the factors that could influence the nature of these outcomes. To capture this uncertainty, we develop a number of REDD+ scenarios and explore how forest tax outcomes could be differentially affected under each scenario, highlighting those scenarios which are likely to create the most positive effects.

The final difference is the policy focus. Even where REDD+ implementation is most advanced (of our case studies, this is Ghana), it remains largely at the capacity building or pilot stage. In the case of Sierra Leone, the REDD+ process is only now at its commencement stage. Cameroon is somewhere in the middle, though closer to Ghana than to Sierra Leone. As most of the key aspects of REDD+ implementation are yet to be finalised in all cases, and have not even been discussed in some, there is an opportunity to influence policy. Accordingly, the final part of this research examines how policy in each country could influence which REDD+ scenarios come to fruition, allowing us to identify policy options to increase the likelihood of positive impacts on forest tax systems in each country.

\subsection{Causal mechanisms for institutional interactions}

This research began with the hypothesis that REDD+ was likely to have significant impacts on forest taxation, and that these impacts could be positive or negative. To go further, we need to think about the precise mechanisms through which these impacts could occur, and link these to policy interventions that could affect them. For Gehring and Oberthür (2009: 126), a 'causal mechanism':

...may be conceived of as a set of statements that are logically connected and provide a plausible account of how a given cause creates an observed effect... In the absence of both firmly established theories of institutional interaction and large- $\mathrm{N}$ studies allowing for statistical analysis, causal mechanisms help distinguish between genuine causality and 'spurious correlation'. They make explicit the underlying causal pathway.

More explicitly:

Institutions are defined as: '... persistent and connected sets of rules and practices that prescribe behavioural roles, constrain activity, and shape expectations' (Keohane 1989: 3, quoted in Gehring and Oberthür 2009). Other authors use the term 'regime' in similar ways, where regimes are defined as: '... institutions possessing norms, decision rules, and procedures which facilitate a convergence of expectations' (Krasner 1983). 
Causal mechanisms provide a micro-foundation for the analysis of institutional interaction and reveal how actors matter in the process... In cases of institutional interaction, both the independent and the dependent variables, i.e. the source institution and the target institution, are located at the macro level. However, an international institution will rarely influence another institution directly without intermediate adaptation of preferences or behaviour by relevant actors. Hence, a concept of institutional interaction requires, like any other theory in the social sciences, a reliable micro-macro link. (p. 127)

REDD+ will not affect forest tax systems directly, but is likely to influence the behaviour of different actors, and it is these changes in behaviour that may cause forest tax system effects. Three different steps are required for any causal mechanism to function in this way (emphasis added):

...a situational mechanism reveals how the source institution affects the preferences or behaviour of relevant actors within its own domain. An actionformation mechanism elucidates how this effect leads to a change of preferences or of individual behaviour of actors relevant to the target institution. In this step, influence is transferred from the domain of the source institution to the domain of the target institution. Finally, a transformational mechanism explains how the adaptation of the individual preferences or behaviour of relevant actors leads to a change of the target institution. (p. 129)

For this research, the 'situational mechanism' is how REDD+ implementation affects stakeholders in the forest sector. The 'action-formation mechanism' describes how this leads to behaviour change, while the 'transformational mechanism' describes how this creates changes with respect to forest tax outcomes.

While any causal mechanism between two institutions can be organised into these categories, Gehring and Oberthür distinguish some key mechanisms, the most relevant of which are described below.

\subsubsection{Cognitive interaction as a causal mechanism}

This mechanism is based upon the power of 'ideas' and the way they are transmitted (Haas 1992). REDD+ implementation may lead to the generation of compelling new ideas or concepts, which change the perspective of actors in the forest tax sector, leading to behaviour change. At the most general level, for example, REDD+ could increase awareness of the importance of environmental issues such as climate change, and the role that forests play in this. This could, in principle, affect the priority given to certain activities - reducing illegal logging, for example - that increase effectiveness, improving outcomes in this area.

What is perhaps more likely is that REDD+ implementation leads to operational innovations that are more effective than existing practice, leading others to adopt similar practices:

Institutions share a number of functional challenges such as monitoring, verification, enforcement and decision making as well as the development of governance instruments... [this] can generally be expected to strengthen the effectiveness of the target institution. (p. 134)

The reference to monitoring, verification and enforcement is particularly relevant, as this is an important overlapping area of concern, where it is possible to imagine influence from REDD+. 


\subsubsection{Behavioural interaction as causal mechanism}

In this form of causal mechanism, we see the situational, action-formation mechanism, and transformational mechanisms most clearly. Gehring and Oberthür (2009: 141) describe the steps in the process as follows:

First, the source institution must produce an output, for example a set of prescriptions or proscriptions. Second, relevant states or non-state actors have to adapt their behaviour in response to the output. Third, the behavioural changes triggered by the source institution must be relevant for the target institution. Behavioural changes may be relevant for both issue-areas, or they may prompt further behavioural changes within the domain of the target institution. Fourth, this behavioural effect has to be relevant for the effectiveness of the target institution.

REDD+ will certainly produce 'prescriptions and proscriptions', potentially affecting outcomes in the sector. We can go further than this, however. As well as formal changes of this kind, REDD+ will have subtler effects. From a governance perspective, for example, REDD+ implementation and operation is likely to influence existing power relations, changing incentives and behaviour. From an economics perspective, the influx of new revenue streams, and the potential impact on existing revenue streams, is also likely to change incentives and thus behaviour.

What determines whether these impacts are positive? The first, and most important, factor is the degree of alignment between the objectives of the two institutions. The more closely aligned these are, the more likely it is that impacts will be positive and vice versa. Where objectives are divergent, or in conflict, then the impact on the 'target institution' is likely to be negative. The strength of these negative effects will be determined by the relative power of actors in each institution. To put it in another way, they will depend upon the extent to which the incumbent institution can prevent the new institution from realising its (contradictory) objectives.

As we shall see, the potential impact of REDD+ on forest tax systems will be strongly influenced by key aspects of REDD+ that remain uncertain. This is true for both the alignment/conflicting nature of REDD+ and tax objectives, and the relative power that REDD+ will have compared with incumbent institutions in our case study countries. The scenarios we have developed have been designed to capture these different eventualities, and to explore the potential behavioural implications of each.

\subsubsection{Impact-level interactions as causal mechanism}

The final forms of causal mechanism to consider are those where behaviour changes triggered by the new institution create direct effects on the objectives of the target institution. For example:

Consider that protection of the stocks of cod and herring are the ultimate targets of two separate international institutions. As cod eats herring, successful protection of cod, resulting in a growing population of this species, will automatically decrease the population of herring. (Gehring and Oberthür 2009: 141)

In this example, a new institution (cod protection) creates behaviour change amongst stakeholders (fishermen) such that they reduce their catches of cod. The unintended consequence, which nevertheless negatively affects the objectives of the incumbent institution (herring protection), is to reduce the quantity of herring. 
The distinction between these types of mechanism and behavioural interactions is that they do not require behaviour change within the incumbent institution (i.e. forest tax), but rather rely on the 'functional linkages' between the two types of institution. For example, it is possible to imagine the global implementation of REDD+ impacting upon timber prices by changing the balance between supply and demand in different markets. This would affect revenues within the forest tax sector.

A key determinant of the nature and strength of potential impacts is the degree of alignment between REDD+ and forest tax objectives, which are briefly summarised below.

\subsection{Objectives of forest tax systems and REDD+}

There are many potential objectives of forest taxation. While we do not suggest that all countries actively pursue all of these goals, our analysis does seek to explore how REDD+ implementation could affect the achievement of objectives in the following areas: revenue raising potential; sustainable forest management (SFM); equitable sharing of forest taxes; promotion of domestic industries; support for sustainable livelihoods; and the promotion of good governance.

The principle objectives of REDD+ are: conservation of existing forest carbon stocks; creation of new forest carbon stocks (reforestation/afforestation); protection of biodiversity; equitable sharing of benefits; and the creation of sustainable livelihoods for forest communities.

At face value, some objectives seem well aligned. Most obviously, both forest taxation and REDD+ have (potential) objectives relating to the equitable sharing of forest benefits. SFM and conservation-related objectives are also aligned. Others are potentially compatible, such as the development of the domestic forestry sector, and sustainable livelihoods for forest communities. In other cases, there is scope for alignment, but also conflict, as with revenue raising and the environmental objectives of REDD+.

In these more ambiguous cases, what will determine the level of alignment or conflict is how the objective is pursued in practice. Raising forest tax revenue can be done in many ways, which are more or less compatible with sustainability objectives, whether these concern the total quantity of forest carbon stocks, or the extent to which forest areas are supportive of biodiversity. Similarly, whether the objectives of developing the domestic forestry sector and creating sustainable livelihoods for forest communities are compatible depends upon what these things mean in practice.

Before applying the conceptual framework, the next section gives some background information on the case study countries, focusing on the forestry sector in general, and forest taxation in particular.

\section{Case study country backgrounds}

\subsection{Cameroon}

Forty-one per cent of Cameroon's territory is covered with forests, which stock at least $5 \mathrm{Gt}$ of carbon (REDD+ Technical Secretariat, Cameroon undated). Between 1990 and 2010, Cameroon lost 18.1 per cent of its forest cover, or around 4,400,000 ha (FAO 2011). The main driver has been conversion for agriculture ( 80 per cent of forest loss) followed by logging and fuel harvesting (MINFOF 2015). Less than 20 per cent of the forest outside 
protected areas remains free from past or planned logging activity (Interview with Center for International Forestry Research (CIFOR), 28 June 2015 in Yaoundé). Illegal logging is estimated to account for half of Cameroon's entire timber harvest (pers. comm. MINEPDED official 2015).

The forest sector is central to Cameroon's economy, accounting for 2.7 per cent of GDP and 49 per cent of taxes, and creating nearly 200,000 formal and informal jobs (pers. comm. MINEPDED official 2015). Forestry has always been important politically, with its resources used to reward political supporters and mobilise support from rural communities for political appointments (Vincent, Gibson, and Boscolo 2005)

The forestry industry is very influential, having long-standing connections with local government and traditional authorities. In remote areas, large foreign companies have even provided services and infrastructure. Historically, French and Italian companies have dominated the sector, but from the 1980s, Greek, Lebanese, and domestic companies have also entered the market. More recently, Asian companies have become increasingly important.

The forestry sector in Cameroon has been undergoing reforms since the mid-1990s. The main changes have been: i) the public auction system for logging concessions and sales of standing volumes introduced by the 1994 law; ii) the (partial) log export ban in $1999{ }^{3}$ and iii) industrialisation induced by the log export ban. Until 1994/1995, the forestry sector was subject to relatively low taxation. The introduction of the Annual Forestry Fee (Redevance Forestière Annuelle - RFA) began to change this, particularly as it has been increased on a number of occasions. The original split for the proceeds of the RFA was 50/40/10 for central government, local government and forest communities respectively.

The main source of forest tax revenue before 1998/1999 was the export tax. Subsequently, the RFA became the main revenue source when the export ban was introduced. Following the global economic crises of 2008, the export tax was reinstated while the RFA was reduced by half. In 2010 , a total of US $\$ 32.2$ million was raised through forest taxation.

Forest tax governance in Cameroon is split across various ministries, with the most important being the Ministry of Forestry and Wildlife (MINFOF), the Ministry of Environment, Nature Protection and Sustainable Development (MINEPDED), and the Ministry of Finance. International actors play a very important role in the forestry sector, forming a 'Consultation Circle of Partners' (CCPM) for MINFOF and MINEPDED. The President remains the most important political actor in Cameroon.

International support for Cameroon's 1994 forestry reforms was partly due to their early adoption of decentralisation. This resulted in four institutional mechanisms: (i) council forests; (ii) community forests; (iii) annual forestry fees; and (iv) community-managed hunting zones. Despite these reforms, forestry taxation remains fairly centralised, with collection and use controlled by central government.

Prior to 1994, forestry revenue did not really benefit local communities. The RFA was partly designed to correct this, stipulating a share to be redistributed to decentralised administrations and rural villages. Amounts received have been variable, with some requirements for channelled funds to be used for health and education spending. In parts of the country that do not receive forest revenues, these costs are covered by central government, causing complaints from forest communities that they are not benefiting from the exploitation of resources in their areas. Municipalities that do not border logging titles are

To enhance sustainability, export of traditional species, such as sapelli, sipo, and iroko, was prohibited, while the export of species to be promoted and other lower value species, such as ayous and azob, was allowed. 
not entitled to the RFA. These excluded municipalities are also the constituencies of some of the most powerful politicians in the country, who are likely to use their influential positions in public life to lobby for their municipalities to benefit from the RFA in the pending forest law (see below).

A 'fiscal recentralisation' law was passed in 2009 in an attempt to address this. The law stipulates that half of the 40 per cent of the RFA received by each municipality must be recentralised for redistribution to all municipalities in the country. To date, however, the mechanism has achieved reversal of previous fiscal decentralisation, rather than redistribution to enhance social equity.

This generates ethnic tensions and also results in IFAs among some local communities in forested council areas who feel they are being treated inequitably, as well as a degree of loss of power by traditional rulers, as community members look increasingly to state authorities for leadership and far less to traditional rulers (community leader in Mbalmayo, 2015).

While Cameroon's 1994 forestry reforms were considered relatively progressive, severe governance problems persist. Partly in response, a draft forestry law is currently pending ratification by parliament. It is reported that the law will have the following objectives: to address the observed flaws in the practice of the law; integrate a regional dimension in the management of forest resources; integrate the commitments entered into by the country at the national level and under regional and international agreements; address the concerns of climate change; take more account of the real capacities of forests in development; improve transparency and governance in the sector; encourage a timber-processing industry that assists the country to develop sustainably; and encourage the full adherence of forest users to the sustainable management of the resource.

\subsection{Ghana}

A quarter of Ghana was originally covered with tropical forest. Ghana has lost a third of its forest cover with the annual deforestation rate estimated at 2 per cent (FAO 2010a), and only 16 per cent of reserves classified as being in very good condition (Hawthorne and Abu-Juam 1995). Forest resources are found in two main zones: high forest and savannah. There are 266 forest reserves in Ghana, which focus on production, protection, conversion and research.

Timber production occurs in almost half of the total area within the forest reserves, with a total annual allowable harvest of $500,000 \mathrm{~m}^{3}$. Timber is also sourced from areas outside forest reserves (off-reserve areas) which are mainly agricultural forest mosaic landscapes with a total annual allowable harvest of 1.5 million $\mathrm{m}^{3}$. Forestry thus plays an important role in national life, earning the country about $€ 138$ million from timber exports in 2014 (TIDD 2014). Its contribution to GDP, however, declined from 3.7 per cent to 2.2 per cent from 2009 to 2013, mainly due to a reduction in timber exports (TIDD 2014).

According to the REDD+ Readiness Proposal for Ghana (GFC 2010), the principal drivers of deforestation and degradation in Ghana broadly are: (i) agricultural expansion (50 per cent); (ii) wood harvesting (35 per cent); (iii) urban expansion and infrastructure (10 per cent); and (iv) mining (5 per cent).

Formally, the ownership of forests is held by stools ${ }^{4}$ in trust for the communities, but all rights over timber are vested in the state. The ownership of land, even if managed as a forest reserve, is not altered. Forest reserves under state management are thus largely still classified as stool lands.

Stool lands are customary units of land usually held in trust for the people by traditional leaders. 
The formal objective of the forest tax system in Ghana is to optimise revenue from the use of forest resources to cover the cost of managing and developing forest resources for the benefit of present and future generations, and to share the benefits equitably. There are ongoing discussions about reviewing the forest tax and revenue system, and paramount amongst these is the constitutional review process. ${ }^{5}$

The forestry sector in Ghana is comprised of several actors with diverse interests. ${ }^{6}$ Powerful interests in the timber industry largely determine the regulation of the sector. The timber industry, for example, has been cited as a powerful actor with significant lobbying power (Kotey, Francois, Owusu, Yeboah, Amanor and Antwi 1998: 79).

Chiefs and traditional authorities were responsible for revenue collection (Kotey et al. 1998) until 1962 when the state took over this role. Today, the place of stools and traditional authorities in the distribution of forest revenue is established in the Constitution. District assemblies (DAs) have also been involved in forestry since 1998, acting as a local implementing agency of central government (Kotey et al. 1998). The performance of the DAs has been weak with respect to environmental management, largely due to resource scarcity and low capacity (Amanor and Brown 2003: 2).

As in other countries, decentralisation in forest management has been taking place, but decision making remains largely centralised. While decentralised units have been created at the regional, district and local levels, critical resources are mainly held and key decisions made nationally, undermining the efficiency and effectiveness of sub-national units and personnel (Hansen and Lund 2011). More than half of forest taxes are held centrally by the Forestry Commission (FC), for example. The central government has also been reluctant to decentralise sectors where revenue generation is high (Amanor and Brown 2003).

In addition to corporation tax, the existing instruments designed for the forest sector/timber industry in Ghana are: concession rent, stumpage fee, timber rights fees, export levy and airdried lumber levy. The most important instrument (revenue wise) is the stumpage fee. It is a volume-based fee charged on harvested timber, which is used to finance the Forestry Commission's regulatory activities and to pay land-owning communities their share of revenue. The Timber Rights Fee (TRF) is an annual lump sum payment for the concession, where rights are awarded to the bidder who offers the highest annual fee. The Forestry Commission collects all timber rights fees. The country's constitution prescribes however that all rents, royalties and revenues from stool lands have to be collected by the Office of Administration of Stool Lands (OASL). So even if the FC in practice collects the fees, the OASL remains the institution responsible for this collection. The Timber Industry Development Division (TIDD) export levies were introduced in 1985 to pay for industry and trade services, and remain an important source of financing for the Forestry Commission.

Contractors bidding to obtain a timber right must include a proposed Social Responsibility Agreement (SRA) in their application. The SRA obliges them to provide benefits to local communities at a cost of no less than 5 per cent of the value of the stumpage fee of timber harvested.

In January 2010 the Constitution Review Commission (CRC) was set up to consult with the people of Ghana on the operation of the 1992 Constitution and any changes that may need to be made to it. This resulted in the publication of a comprehensive (960 pages) report titled 'From a Political to a Developmental Constitution'.

Actors with respect to timber resources include the Ministry of Finance and Economic Planning (MOFEP), the Forestry Commission through the Timber Industry Development Division (TIDD), the Office of the Administration of Stool Lands (OASL), traditional councils, stools, district assemblies, forest communities, and Ghana Timber Millers' Organization (GTMO), Chainsaw Lumbers, Wood Workers Association, Ghana Timber Association, Chartered Institute of Builders, Domestic Lumber Trade Association of Ghana (DOLTA) and the timber firms. 
While no systematic analysis of the contribution of different tax instruments has been done, a few studies have looked at particular fiscal years (e.g. Hansen and Lund 2011; Birikorang, Okai, Asenso-Okyere, Afrane and Robinson 2001; FC 2008). Hansen and Lund (2011) provide the most detailed analysis, using 2005 revenue, as shown in Table 1.

Table 1 Ghana's forest tax revenues, 2005

\begin{tabular}{|l|l|l|l|}
\hline \multirow{2}{*}{ Fee/tax } & \multicolumn{2}{|l|}{ Total revenue } & $\begin{array}{l}\text { Percentage of total timber tax } \\
\text { revenue }\end{array}$ \\
\cline { 2 - 4 } & $\begin{array}{l}\text { Billion Ghana } \\
\text { Cedi (GHC) }\end{array}$ & Million US\$ & Per cent \\
\hline Stumpage fee and concession rent & 80.4 & 8.9 & 45 \\
\hline 1 per cent and 2 per cent export levies & 50.2 & 5.5 & 28 \\
\hline Air-dried export lumber levy & 2.8 & 0.3 & 1 \\
\hline Corporation tax & 47.6 & 5.2 & 26 \\
\hline Total & $\mathbf{1 8 1 . 0}$ & $\mathbf{1 9 . 9}$ & $\mathbf{1 0 0}$ \\
\hline
\end{tabular}

By far the largest source of revenue is the stumpage fee and export levies even though Government of Ghana subvention forms the highest, which mainly covers salaries of FC staff (see Table 1).

The constitution stipulates how forest benefits should be allocated among stakeholders: 25 per cent for the stool; 20 per cent to the traditional authority; and 55 per cent to the district assembly. The translation of these provisions in practice has been a source of conflict, however (Marfo 2006). In 2005, for example, while a third each went to government and the FC, only 13 per cent was shared among stool administrators, traditional authorities (chiefs and traditional councils) and the district assemblies (Hansen et al. 2011). It has also been reported that some funds earmarked for forest communities do not reach them, and, where they do, they are taken by traditional authorities (Hansen and Lund 2011). ${ }^{7}$

\subsection{Sierra Leone}

Forest resources in Sierra Leone consist of protected areas and off-reserve forest areas. The protected areas, covering approximately 4 per cent of the country, include 36 forest reserves, five game reserves, two game sanctuaries, seven national parks, four non-hunting reserves, and nine nature reserves (UNEP WCM 2007). Sierra Leone's rainforests, mangroves and savannah forests host a high level of endemic and globally rare and threatened species. The Upper Guinean Forest ecosystem, which hosts the Gola Forests in the east of the country, is listed on the World Wildlife Fund's (WWF) 'Global 200' list of critical regions for conservation and is included as one of Conservation International's 34 global biodiversity hotspots (Brown and Crawford 2012).

Between 1990 and 2010, deforestation rates averaged 20,000 ha per year. In 2010, this equated to 0.7 per cent of the total forest cover (FAO 2010b). Deforestation in the western area has been particularly rapid since the civil war of 1991-2002, which created an inflow of refugees to the capital, putting pressure on adjacent forested areas. Perhaps the most alarming effects of increasing deforestation have been changes to the water catchment area. As the water catchment forest has shrunk, the relationship between surface runoff, groundwater recharge and dry season water supplies has changed. An earlier study of the Bambara stream found that its water level had declined by one third during the 1990s (USDA Forest Service 2000). Similarly, the Kongo Dam, which together with the Guma Dam supplies water to Freetown and other communities around the Peninsula area, was reported to have dried up almost completely towards the end of the rainy season in 2004 (USDA Forest Service 2000). As recently as August 2017, the forested area of Mount Sugar Loaf, which forms part of the Western Area National Park, experienced a landslide that killed

For example, Marfo, Acheampong and Opuni-Frimpong (2012) estimate that 45 per cent of forest revenues that go to these stakeholders end up with traditional leaders without any mechanism to ensure equity and accountability. 
hundreds of inhabitants. This disaster has been widely associated with deforestation along the foot of the mountain, where residents had built houses beyond the demarcated forest belt.

The drivers of deforestation include shifting cultivation, wild fires, mining of minerals, stone and sand (largely induced by population pressures in the coastal areas of Freetown due to the civil war), logging for timber, firewood harvesting for sustenance and charcoal. One major by-product of the war-induced poverty in the country is the introduction of individually operated power saws as a source of livelihood; these are often used in remote areas where they are difficult to police due to their mobile nature (MAFFS 2014).

The forestry sector employs 11.5 per cent of the country's labour force. The sector's share of GDP stands at 14.8 per cent, much higher than the average for West Africa (3.7 per cent) and Africa (2 per cent). Timber and non-timber forest products provide employment as well as contributing to livelihoods in other ways. Forests provide a range of non-timber products and services including fruit, nuts, oils, medicinal plants, bushmeat, honey and wax, rubber, fuel wood, wildlife conservation, watershed management, agro-forestry, and carbon credits. Communities in the Peninsula Mountain forests use forests for charcoal burning, sand mining, and stone mining, and use wood fuel for fish processing and household cooking energy. Over 80 per cent of Sierra Leoneans rely on fuel wood as their primary source for household energy (USDA Forest Service 2000). Ninety-two and a half per cent of Sierra Leoneans use wood fuel for cooking, a proportion much higher than for West Africa and Africa respectively. Demand is expected to increase as the population rises.

In Sierra Leone, forests are largely privately owned, with government owning 14 per cent. As of 2005 , all private forests are formally owned by local, indigenous and tribal communities (FAO/UNDP 2011). Despite low formal ownership, the government has regulatory power over the use of all forests.

Key stakeholders involved in the sector are the Forestry Division (FD) of the Ministry of Agriculture, Forestry and Food Security (MAFFS), the National Protected Area Authority (NPAA), the Environmental Protection Agency (EPA), the European Union (EU), local government, and forest communities. The FD sits within MAFFS and is the main institution responsible for the management of forestry and wildlife in Sierra Leone. Previously, the FD had three functional units: commercial, community, and conservation. However, the last of these was reformed and changed in 2012 to the new, semi-autonomous NPAA.

Though not as important as central government, municipal authorities and local councils are involved in the collection of forest revenues, particularly transport permits for taking forestry products to urban areas. As elsewhere, decentralisation has not been without problems, with unclear definition of roles, and poor coordination between the local councils and the MAFFS. This has resulted in overlapping of functions, as well as some misunderstanding (particularly in revenue generation) (MAFFS 2014). Other important stakeholders are the donor community, international and domestic NGOs, private firms (including chainsaw operators), and local communities, particularly traditional rulers.

Major forest tax reviews were held in 1989, 1999, 2004, 2008 and 2014, entailing the creation of new taxes and revisions to tax rates. A key factor that has influenced the changes in tax instruments over time is the civil war, and the resultant breakdown in law and order. A second issue is the very low fees and royalty rates, which have boosted demand for forest exploitation. ${ }^{8}$ On average, forestry tax rates from 1989 to 1999 more than trebled. From 1999 to 2004, rates increased by 352 per cent. From 2004 to 2008, the increase was 1,215 per

A comparative survey with neighbouring countries done by the FD found that Sierra Leone's export fee for timber products is comparatively lower than these other countries, and suggested that this was causing higher demand for logging in Sierra Leone. 
cent. From 2008 to 2014, both tax and royalty rates increased by an average of 110 per cent. The changes in rates over the years have been considerably higher than the changes in revenues mobilised. For example, revenues from the export of forestry products grew by 33 per cent from 2008 to 2013.

The primary forest taxes and related instruments used in Sierra Leone are: export taxes, concession licence fees, land leases (i.e. concession rent), registration fees (for power saws), transport permits, stumpage fees, royalties, reforestation fees, training fees, and revenues from fines. Despite the plethora of instruments, most revenues come from concession licences, timber export fees and forest products transportation permits. Of these, timber export fees have contributed by far the largest amount, peaking at US $\$ 865,000$ in 2011. A ban on logging implemented in 2014 led - unsurprisingly - to a sharp fall in revenues. The official rationale was to control illegal logging, and put systems in place to regulate the timber industry. The revenue effect of this ban on timber logging is reflected in the revenue collection data over the past years. There were no revenues from timber export since early 2014 when the ban was renewed and the Chief Timber Operator arrested alongside the government's Chief of Staff because of their alleged operations in the midst of the ban. This led to the dismissal of the Chief of Staff, who was eventually freed and the matter dismissed from court.

Even before the ban was imposed, revenues were very low. In 2005, for example, the FAO/UNDP (2011) estimated total forest revenues at just US\$648,000, compared with US\$1.09 million in public sector costs relating to the forestry sector. Forest tax revenues in Sierra Leone are low compared to other sectors of the economy and compared to other key forestry countries in Africa. Even in the Eastern District of Kenema where the country's largest stock of forest cover is located, revenues are minimal. Average monthly revenue from forestry activities, according to the District Forestry Officer in charge, is estimated to be around 10-12 million Sierra Leonean Leones (US\$2,000-US\$2,400).

However, between 2014 and September 2017, the government twice lifted the ban on timber exports and on both occasions the National Revenue Authority (NRA) reported much higher collection from accumulated stock of timber exports. In a single month in 2017 (August), collection from timber export fees as reported in the revenue records of the NRA of Sierra Leone totalled US\$1.6 million. Whilst this amount seems high, it should be noted that it is largely the result of the accumulation of stock of timber during the periods of enforcement of the export ban.

The distribution of financial benefits from forest exploitation according to the Forestry Division is as follows: paramount chief 10 per cent; chiefdom administration 30 per cent (for chiefdom development purposes); local council 20 per cent (for council development purposes); land owners 40 per cent. These allocations are applied to community concessions only. The government takes all revenues from state-owned forests.

Location is key in determining the beneficiaries of forests. In the western area the main beneficiary is the government through revenues from concessions. In rural areas where community ownership of land is common, the communities are the beneficiaries of forest resources, including tax revenues. 


\section{Analysis of regime interaction and policy options in case study countries}

The remainder of this paper is organised as follows. First, the different REDD+ scenarios that could emerge are outlined, and the principal governance and economic effects that these could have in each country are assessed. As we have seen, most REDD+ impacts will be mediated through the behaviour of stakeholders rather than felt directly. To capture this, key stakeholders in the forestry sector in each country were mapped, and an assessment made of how their interests could be affected by the 'consequences' of REDD+ implementation under different scenarios. These micro level behaviours were then linked to macro level impacts with respect to the forest tax objectives listed above. Subsequently, direct causal mechanisms from REDD+ to forest tax outcomes were also assessed. The final part of the paper returns to the REDD+ scenarios in the light of these analyses, identifies 'preferred scenarios', and explores how policy in each country could affect these.

\subsection{REDD+ scenarios}

A number of important aspects of REDD+, which will strongly influence the impacts that it has, remain to be determined. Some of these are located at the global level, while most are domestic. By 'global' or 'domestic', we mean whether or not these issues will be settled globally or nationally.

Table 2 gives the main scenarios considered. Although there are 12 listed here, the actual number of scenarios is more than double this, as each example here contains at least two separate scenarios. 'High vs. low' participation is two scenarios, one 'high participation' and one 'low participation.'

Table 2 REDD+ implementation scenarios

\begin{tabular}{|l|l|}
\hline \multicolumn{2}{|l|}{ Global factors } \\
\hline 1 & Governance conditionality vs. non-conditionality \\
\hline 2 & High vs. low REDD+ finance (national) \\
\hline 3 & High vs. low REDD+ finance (per carbon unit) \\
\hline 4 & High vs. low timber export prices (and agricultural commodities) \\
\hline Domestic factors \\
\hline 5 & High vs. low domestic timber prices (and agricultural commodities) \\
\hline 6 & Extensive vs. limited coverage \\
\hline 7 & Effective vs. ineffective monitoring, reporting and verification (MRV) \\
\hline 8 & High vs. low participation \\
\hline 9 & Equitable vs. inequitable benefit sharing \\
\hline 10 & National, district or project level implementation \\
\hline 11 & Sector vs. non-sector implementation \\
\hline 12 & Existing vs. new channels of disbursal \\
\hline
\end{tabular}

\subsubsection{REDD+ scenarios and global factors}

The first global factor that is relevant from a scenario perspective is whether, and to what extent, REDD+ financing will come with conditionality from a governance perspective, and how strictly this would be enforced. Conditionality that leads to improved governance in the forestry sector is also likely to have positive impacts on the governance of forest tax systems. 
The actual level of REDD+ financing that will be available each year is unclear. The Paris COP (the 2015 United Nations Climate Change Conference) saw developed countries recommit to raise US $\$ 100$ bn per year by 2020 . Whether this commitment will be met in full, and what sort of finance this involves, remains uncertain. Beyond this, it is unclear what proportion of total finance will be allocated to REDD+ and, which may be of more practical importance for countries that are potential recipients of finance, how this will be allocated between countries. As well as donor financing, it is unclear whether carbon markets will play any important role in future climate finance and, if so, what role REDD+ could play in this. While there is no shortage of estimates of what finance is needed to support REDD+ activities, there is fundamental uncertainty over what the total supply of finance will be, how it will be allocated between countries, and what global mechanisms (e.g. market vs. nonmarket based) will be used.

When we consider the potential impacts of REDD+ on governance systems, as well as economic effects on the forestry sector, this is obviously key. In one scenario REDD+ is well funded at the global level, and participating countries receive large annual financing. At the other extreme, global REDD+ finance could be far less than hoped, with the result that recipient countries receive relatively limited annual financing. The governance impacts - for example on the relative power of different institutions and actors - will be far stronger in the first scenario than the second. Similarly, the impact that REDD+ could have on the economics of forestry - through changing relative prices for example - will be more pronounced in situations where the level of finance is higher.

This takes us to the third factor in Table 2 (high vs. low REDD+ finance per carbon unit). While the total quantity of REDD+ finance at the country level sets the boundaries of its impact, and will have a strong influence on relative power and prestige, economic impacts may be more influenced by what we might call the 'price' of REDD+ finance. By this we mean the amount of finance that is available per unit of carbon. It is this 'price' that will determine the extent to which REDD+ will influence relative prices in the forestry sector.

Forestry competes with many other potential land uses, particularly agriculture. Generally, forestry has been the lowest yielding land use, creating incentives for conversion. In this regard, a number of important price thresholds exist with respect to REDD+. First, if the annual value of finance per unit of carbon exceeds that available for a tree from commercial felling, an incentive is created to leave the tree standing. If this is extended across a large enough area, an economic incentive is created for forestry concessions to become 'REDD+ concessions', as the commercial return would be greater. While this would prevent deforestation from commercial forestry, other price thresholds would have to be reached to do the same with other forms of land use.

Of course, we are interested in relative rather than absolute pricing levels. What matters is how REDD+ returns per hectare compare with those available from forestry and other potential land uses. For the export sector, this will be determined by the global prices of relevant commodities: timber, hardwood or agricultural products. When these prices are high, the value of REDD+ finance would also have to be high, suggesting that to retain its ability to influence deforestation pressures via economic incentives, the value of REDD+ finance would need to be linked to the global prices of relevant forestry and agricultural commodities.

It is important to recognise that this 'opportunity cost' approach is only appropriate under certain conditions: when countries have forest areas where commercial forestry is permitted. In these circumstances, the opportunity of different land use is a good approximation of the value REDD+ finance would need to reach to affect economic incentives. As detailed in Gregerson, El Lakany, Karsenty, and White (2010), however, this does not apply in a number of cases. First, where commercial forestry is already prohibited as an area is under some 
form of environmental protection. Although illegal activity may be taking place, the authors argue that it is not appropriate to take this revenue as an opportunity cost that REDD+ must match. Rather, the relevant cost is what would be needed to enforce the prohibition.

The point is that although the total benefits of preventing illegal forest activities may be large, this is not necessarily true for all stakeholders. Where those stakeholders have an influence over policy, it is not difficult to see how implementing effective policy can be very difficult. In principle, it could be possible to calculate the opportunity cost of effective enforcement (i.e. what would be lost in illegal payments) and design incentives to address this. This is a much wider issue of governance, which may be particularly pronounced in the forestry sector, but is not unique to it.

A second case where using opportunity costs may be inappropriate is where there is uncertainty or there are disputes over land rights, particularly where the traditional rights of indigenous peoples and forest communities conflict with the ownership rights of the state, or the commercial rights of private companies. In most cases, these local communities do not operate within a market economy context, or do so only at the margin. While considerable progress has been made in clarifying and legitimising traditional rights in the Brazilian Amazon, this is not the case in many other countries. Indeed, the risk is that the advent of REDD+ creates the opposite effects:

These people at present are for the most part merely tolerated by governments because there is no other economically pressing demand on the land and moving them off the land would create pressing social and security problems and could involve major costs. With the incoming REDD+ funds, governments now could see some economic value in instituting coercive measures to have these groups stop any deforestation they are causing. Governments might establish preserves and not compensate adequately (the opportunity costs of) the groups that were using the land beforehand, thus creating a serious socioeconomic problem and a likely problem in terms of halting illegal use of the new preserves. (Gregerson et al. 2010: 11)

If this risk could be avoided, which would seem an essential precondition to the fair and effective implementation of REDD+, calculating appropriate compensatory payments would be far from straightforward. The crucial point is that implementing REDD+ effectively will require long-standing and difficult issues such as land rights and tenure to be resolved, at least to some extent. More broadly, if the goal is to provide alternative 'ways of life' for some forest communities, this becomes a much more ambitious task, the costs of which are likely to far exceed current REDD+ estimates.

While the value of REDD+ payments may be largely determined on a global basis, estimating these in practice is impossible without full account being taken of local conditions. Global and domestic factors in terms of REDD+ implementation will therefore be inextricably intertwined.

\subsubsection{REDD+ scenarios and domestic factors}

As well as questions that are outside the influence of national governments, a number of key elements of REDD+ will be determined by decisions taken domestically. The first listed in Table 2, which follows on from the previous discussion, is whether domestic timber prices (and those of other agricultural commodities) are high or low. While there is a relationship between the global and local prices of these goods, the transmission is far from 100 per cent. In many cases, the dynamics of the domestic market are very different from that operating globally, particularly in the forestry sector. In Ghana, for example, most of the permissible annual cut (i.e. the quantity of trees that can be legally harvested) goes to the export sector. The domestic sector, therefore, is largely served by timber from illegal logging, not least as 
there are fewer controls over its sale domestically. Unsurprisingly, therefore, domestic prices are quite disconnected from those which pertain globally. When considering how economic incentives could affect behaviour via REDD+ finance, we also need to compare these with what is available in the domestic market.

The relationship between the formal and informal sectors is very important here. If REDD+ finance can only be made available to those operating legally in the forestry sector, but much illegal logging is carried out by informal 'chainsaw operators' who cannot receive these benefits, then REDD+ cannot affect the incentives of these actors, regardless of its overall national level and carbon value.

The second factor is whether the domestic areas affected by REDD+ are extensive or limited. By the latter, we mean that REDD+ is largely or entirely implemented in areas that are already protected from an environmental perspective. By 'extensive' coverage, we mean that REDD+ is implemented in areas that are currently used for forestry, or other commercial land uses. If coverage is limited, then the economic effects discussed above would be less relevant. If attempts are made to extend REDD+ programmes into areas where they would need to compete with alternative land uses, then these potential effects become highly relevant, and the value of REDD+ finance per unit of carbon a crucial driver. As well as these economic effects, which would alter the economic incentives of important forestry sector stakeholders, governance impacts - in terms of the relative power and influence of different actors - would be expected.

A third important factor that will largely be determined domestically is whether monitoring, reporting and verification (MRV) is effective or not. This will be crucial in determining whether REDD+ succeeds regardless of whether its coverage is limited or extensive. In the former case, currently protected forest areas may not have commercial logging, but they do suffer from illegal logging of all forms. The extent to which REDD+ is able to reduce this will be largely determined by how effective domestic MRV procedures are. If REDD+ coverage is extended into areas that are not currently protected, then MRV procedures will need to be stronger still, as the commercial pressures driving deforestation will be significantly higher.

The next two factors are closely related. The first contrasts scenarios where a wide range of stakeholders have been involved in the design and implementation of REDD+ programmes ('high participation') with those where these have been centrally imposed ('low participation'). The second issue is whether REDD+ financing (and related benefits) are distributed equitably or inequitably amongst different stakeholders. While there will be disagreement over what qualifies as 'equitable' in this regard, it seems likely that the more equitable (and meaningful) the participation in REDD+ programme design and implementation, the more likely it is that the benefits of these programmes will also be distributed equitably. Questions of benefit sharing are inextricably linked to ownership rights, where conflicts between the 'traditional rights' of forest communities, the commercial rights of private operators, and the ownership rights of government are central. How these questions are answered will have a strong influence on the interests and incentives of different groups, and will therefore be a significant input into the 'behavioural causal mechanism' described above.

The final three factors as listed in Table 2 all consider how REDD+ is implemented in practice, particularly the level and institutions through which finance is channelled. The first question is whether this occurs at the national level (i.e. where REDD+ finance goes to central government and is then distributed), or the local/district level (i.e. where some or all finance goes to local government), or the project level (i.e. where finance goes directly to REDD+ projects without being intermediated by state agencies).

Assuming that the state retains a significant role, the second question is whether REDD+ is implemented through forestry institutions or other agencies. The third question is whether 
existing channels for the disbursal of forest-related funds are used, or whether new institutions are created to do this. As has been described above, for example, traditional rulers and their administrations play an important role in distributing current forest tax revenues in all of our case study countries. Would they have a similar function within REDD+ programmes? This final set of domestic factors will have a strong influence over whether REDD+ entrenches existing problems (of nepotism for example), builds upon existing successes where they exist, or starts afresh with the potential for greater change.

\subsection{Forms of REDD+ consequences in three countries}

In this section we describe some of the changes that may result from REDD+ implementation in two areas: governance and economics. For governance, this refers to new institutions that will be established, and existing institutions that will be reformed, or significantly affected. Similarly, from an economic perspective, this refers to new revenue streams that will be created, and existing revenue streams that will be affected.

Table 3 summarises the impacts of REDD+ implementation that we currently know about in our case study countries. As we can see, each country has seen a number of new institutions established as a result of REDD+. In Cameroon, the REDD+ Steering Committee is comprised of eight government ministries and agencies, civil society groups, indigenous peoples, the private sector and local elected officials. The most powerful ministry on the committee, and with respect to REDD+ implementation, is the Ministry of the Environment, Nature Protection and Sustainable Development (MINEPDED). A Technical Secretariat (TS) has also been established under MINEPDED to establish criteria for REDD+ pilot projects. The TS will also work with the National Observatory on Climate Change (ONACC) to establish carbon stocks and monitor the social and environmental impact of REDD+ projects. The TS and ONACC will oversee Cameroon's MRV system.

As well as these national governance institutions, Cameroon has also established Regional Coordination Units to help communities prepare for REDD+, as well as Conflict Resolution Committees to address and resolve disputes between stakeholders on REDD+ implementation and practice. Finally, the Consultation Circle of Partners of MINEPDED and MINFOF (CCPM) has been established to coordinate donor support for forestry and the environment through the activities of MINFOF and MINEPDED and essentially acts as mediator and facilitator between national actors on matters of forestry and REDD+.

While REDD+ implementation has also led to the establishment of a National REDD+ Steering Committee (NRSC) in Ghana, the key actor is the REDD+ Secretariat, based in the Forestry Commission (FC). In the early days of REDD+ discussions, the FC successfully argued that REDD+ was essentially a forestry issue (rather than an environmental or financial issue, for example) and so should come within its remit. The fact that Ghana's FC was already well-resourced and respected, and politically influential, obviously strengthened these arguments. The result, however, is that the FC has been the principal driver of REDD+ activities in Ghana. The final important institution to be established is the FC Climate Change Mainstreaming Committee to ensure that climate programmes such as REDD+ do not stand alone and that planning and forest operations effectively integrate climate change issues. 
Table 3 Current and anticipated governance and economic impacts of REDD+ implementation

\begin{tabular}{|c|c|c|}
\hline Cameroon & Ghana & Sierra Leone \\
\hline \multicolumn{3}{|c|}{ Establishment of new institutions } \\
\hline $\begin{array}{l}\text { REDD+ Steering } \\
\text { Committee }\end{array}$ & National REDD+ Steering Committee (NRSC) & $\begin{array}{l}\text { National Protected Area Authority } \\
\text { (NPAA) }\end{array}$ \\
\hline Technical Secretariat & REDD+ Secretariat & $\begin{array}{l}\text { Company created for management of } \\
\text { Gola forest carbon credit trade }\end{array}$ \\
\hline $\begin{array}{l}\text { The National Observatory } \\
\text { on } \\
\text { Climate Change (ONACC) }\end{array}$ & $\begin{array}{l}\text { Forestry Commission Climate Change } \\
\text { Mainstreaming Committee }\end{array}$ & Regional REDD+ committees \\
\hline $\begin{array}{l}\text { Regional coordination } \\
\text { units }\end{array}$ & & Multi-stakeholder committees \\
\hline $\begin{array}{l}\text { Conflict resolution } \\
\text { committees }\end{array}$ & & $\begin{array}{l}\text { Technical interventions on charcoal } \\
\text { production }\end{array}$ \\
\hline CCPM (donor 'circle') & & \\
\hline \multicolumn{3}{|c|}{ Reform of existing institutions and activities } \\
\hline $\begin{array}{l}\text { REDD+ control moved } \\
\text { from MINEP to } \\
\text { MINEPDED }\end{array}$ & $\begin{array}{l}\text { National REDD+ Steering Committee (NRSC) } \\
\text { expanded to include representatives of the EU } \\
\text { FLEGT (Forest Law Enforcement, Governance } \\
\text { and Trade) scheme Voluntary Partnership } \\
\text { Agreement (VPA) }\end{array}$ & $\begin{array}{l}\text { Forestry Division reduced by removal of } \\
\text { conservation unit, which was upgraded } \\
\text { to a semi-autonomous authority (the } \\
\text { NPAA) }\end{array}$ \\
\hline $\begin{array}{l}\text { Domestic NGOs } \\
\text { established and/or } \\
\text { empowered }\end{array}$ & MRV system made more elaborate & $\begin{array}{l}\text { Environmental Protection Agency (EPA) } \\
\text { expanded to include the National } \\
\text { Climate Change Secretariat }\end{array}$ \\
\hline $\begin{array}{l}\text { Civil society organisations' } \\
\text { (CSOs) and communities' } \\
\text { participation } \\
\text { in REDD+ pilots }\end{array}$ & & $\begin{array}{l}\text { Ministry of Finance and Economic } \\
\text { Development (MOFED)/National } \\
\text { Revenue Authority (NRA) given } \\
\text { responsibility for new revenue source }\end{array}$ \\
\hline $\begin{array}{l}\text { Holding of } \\
\text { regional/divisional } \\
\text { consultations }\end{array}$ & & CSOs participation in REDD+ pilots \\
\hline & & More/better enforcement (i.e. MRV) \\
\hline \multicolumn{3}{|c|}{ New revenue streams established } \\
\hline \multicolumn{3}{|l|}{ Capacity building finance } \\
\hline \multicolumn{3}{|l|}{ Pilot projects finance } \\
\hline \multicolumn{3}{|l|}{ Long-term carbon finance } \\
\hline \multicolumn{3}{|c|}{ Existing revenue streams affected } \\
\hline \multicolumn{3}{|l|}{ Concession fees rise/fall } \\
\hline \multicolumn{3}{|l|}{ Export fees stable/fall } \\
\hline \multicolumn{3}{|l|}{ Stumpage fees rise/fall } \\
\hline Alternative land use revenu & rise/fall & \\
\hline
\end{tabular}

The most important new institution established in Sierra Leone is the National Protected Area Authority (NPAA), which was formed out of the former Conservation Unit of the Forestry Division and is the lead agency for REDD+ implementation. The Ministry of Agriculture, Forestry and Food Security (MAFFS) oversees both of these agencies. Another important new institution is the not-for-profit company established to manage the trade in Gola Forest carbon offsets in the voluntary carbon market. As in Cameroon, Regional REDD+ Committees are on the verge of being established to serve as reference points for REDD+ in the regions. A multi-stakeholder committee is planned but not yet established largely due to the Ebola outbreak in the country. The rationale for the multi-stakeholder committee is to facilitate involvement of all parts of society in the propagation and adoption of the REDD+ mechanism. Sierra Leone is also in the process of implementing pilot projects on sustainable charcoal, a move started by the Ministry of Energy and being considered as an activity under the EU funded REDD+. The rationale for such a move is to change how charcoal is produced and used to reduce negative impacts on conservation and on the national forest reserves. 
The establishment of these institutions has, in some cases, directly impacted upon existing institutions. In Cameroon, the Ministry of Environment and Nature Protection (MINEP) was expanded in 2012 to form the Ministry of Environment, Nature Protection and Sustainable Development (MINEPDED), which included sustainable development issues and was therefore a more natural home for REDD+. In Ghana, the Natural Resource and Environmental Committee (NREC), an inter-ministry body that might have been expected to obtain oversight of REDD+, was expanded to include representatives of the EU FLEGT programme.

In Sierra Leone, the Forestry Division was reduced in size when its conservation unit was split off, turned into the NPAA, and given responsibility for REDD+. The Environmental Protection Agency (EPA) has also been expanded to incorporate the National Climate Change Secretariat (NCCS). The NCCS was established after Sierra Leone became a signatory to the Kyoto Protocol, and had been charged with developing climate change policy and establishing a regulatory framework to enable Sierra Leone to participate in the Clean Development Mechanism (CDM) and REDD+. Despite this, the NCCS did not get oversight of REDD+ because the management of forests and conservation does not rest with them, but with the NPAA. The Ministry of Finance and Economic Development (MOFED) and National Revenue Agency (NRA) have responsibility for revenues from REDD+.

Other governance impacts are less concrete and continue to evolve. Implementation has seen more involvement of civil society organisations in REDD+ activities. A pilot payment for environmental services (PES) project has been implemented by CED, a national NGO, for example. Although no national or subnational fund and/or benefit-sharing mechanism for REDD+ has been established in Cameroon, WWF and other NGOs have been building wildlife monitoring capacity within local communities. The impact of these final institutional changes will be determined by answers to the questions considered above on REDD+ scenarios, and so will be considered in more detail below.

Turning to new revenue streams, we can distinguish three different types. First, there is finance to support capacity building - i.e. 'REDD + readiness'. To a greater or lesser extent, all of our case studies have received finance of this kind. Second, there is finance to support the implementation of pilot projects. While both Ghana and Cameroon have obtained significant finance in this form, Sierra Leone has not yet reached this stage in REDD+ notwithstanding the Gola Forest project which has been separately funded by the Royal Society for the Protection of Birds (RSPB). The third form of new revenue stream is longterm carbon finance to support REDD+ objectives, which is our primary area of interest in terms of new financial flows. While none of our countries have been recipients of this kind of finance, one goal of this study has been to explore its potential impacts. As described above, this will largely be determined by the scale, form and value of REDD+ financial flows in the future. The impact of these different scenarios in this regard will be explored below.

The economic impacts on existing revenues will be similarly contingent on these scenarios. Table 3 (above) describes four main types of potential impact, where REDD+ finance could affect current revenue streams from: a) forest concessions; b) forestry exports; c) stumpage fees; and d) alternative land uses (such as agriculture). There are two forms of potential impact. First, REDD+ could lead to a higher or lower volume of revenues by increasing or decreasing the quantity of each activity. A second potential impact is through the rate of return on these activities. The higher the value of REDD+ finance in terms of yield per hectare, and the more REDD+ coverage extends into forest areas that are not currently protected, the more we would expect to see a lower quantity of non-REDD+ forest activities and so lower revenues. If areas previously used for commercial forestry become protected under REDD+ programmes, the volume of revenues from forestry will fall. 
To consider the impacts that these kinds of governance and economic changes could have under different scenarios, we need to consider how they could affect the main stakeholders in the forestry sector in each of the case study countries.

\subsection{Behavioural impacts under different scenarios}

Stakeholders are organised into four groups: central government agencies; decentralised/local agencies; private sector actors; and NGOs, civil society organisations (CSOs) and donor organisations. The formal and informal roles and interests in forest taxation and REDD + were identified as part of the research, and an assessment made of how these could be affected under different REDD+ scenarios. These findings are presented in summary form here.

Impacts are either positive $(\sqrt{ })$, negative $(x)$, neutral (-), or uncertain (?). While scenarios are assessed individually, the final impact will depend upon their combination in many cases. For example, the impact of a scenario where countries receive significant REDD+ financing ('high REDD+ finance - national') will vary depending on the unit value of this finance (high/low REDD+ finance per unit).

\subsubsection{Cameroon}

Table 4 details the potential impact on stakeholders in Cameroon of REDD+ implementation under different global scenarios (i.e. those that will be settled by decisions at the local or the global level). The shaded/unshaded areas highlight the categories of stakeholder.

Respectively: central government; local government; private sector; and donors/NGOs/CSOs.

The first scenario concerns whether REDD+ finance comes with or without conditionality. Generally, central government agencies would prefer no conditionality, as this gives them more room for manoeuvre. The exception is the Ministry for Social Affairs (MINAS). As MINAS is concerned with enhancing the benefits received by local communities, conditionality may increase the probability of this happening.

For decentralised/local entities, $\mathrm{SGS}^{9}$ is likely to benefit from conditionality that leads to improved governance, as this should reduce IFAs and non-compliance (for both tax and REDD+), making its monitoring and verification easier than would be the case otherwise. If conditionality extends to the activities of local councils, they are likely to view this in a similarly negative way to central government agencies. On the other hand, local communities may benefit from more effective governance if this leads to their receiving more benefits from tax/REDD+, but only if these benefits outweigh any lost through more restrictions on IFAs.

For private sector stakeholders that have learned to operate in the existing governance environment, conditionality - that is effective - may be viewed negatively. Over the longer term, however, a more effective governance regime may be positive for private actors. So while existing stakeholders would be likely to oppose (hence the negative mark), perspectives over the longer-term could change on this issue. Donors, NGOs and CSOs would be more likely to view conditionality favourably.

The second scenario concerns the total level of annual REDD+ financing received, while the third deals with the relative returns available from REDD+ compared with different land uses. 'High REDD+ finance per unit' means that the potential returns from REDD+ in a given area are at least equal to those that could be obtained from forestry (and competitive with those

SGS is a global inspection, verification, testing and certification company. It plays a key role in monitoring Cameroon's forestry sector. http://www.sgs.com/ 
from other land uses such as agriculture). This therefore also captures price movements in timber and other commodities.

Table 4 Stakeholder impacts in Cameroon under global scenarios

\begin{tabular}{|c|c|c|c|c|c|c|}
\hline \multirow[t]{2}{*}{ Scenario } & \multicolumn{2}{|l|}{1} & \multicolumn{2}{|l|}{2} & \multicolumn{2}{|l|}{3} \\
\hline & $\begin{array}{l}\text { Governance } \\
\text { conditions }\end{array}$ & $\begin{array}{l}\text { No } \\
\text { conditions }\end{array}$ & $\begin{array}{l}\text { High } \\
\text { REDD+ } \\
\text { finance } \\
\text { (national) }\end{array}$ & $\begin{array}{l}\text { Low } \\
\text { REDD+ } \\
\text { finance } \\
\text { (national) }\end{array}$ & $\begin{array}{l}\text { High } \\
\text { relative } \\
\text { REDD+ } \\
\text { finance } \\
\text { (per unit) }\end{array}$ & $\begin{array}{l}\text { Low } \\
\text { relative } \\
\text { REDD+ } \\
\text { finance } \\
\text { (per unit) }\end{array}$ \\
\hline Prime Minister's Office/Presidency & $\mathrm{X}$ & $\sqrt{ }$ & $\sqrt{ }$ & $\bar{X}$ & $\sqrt{ }$ & $\bar{X}$ \\
\hline $\begin{array}{l}\text { MINFOF (Ministry of Forestry and } \\
\text { Wildlife) }\end{array}$ & $\mathrm{X}$ & $\sqrt{ }$ & $?$ & $\sqrt{ }$ & $?$ & $\sqrt{ }$ \\
\hline $\begin{array}{l}\text { MINFI (Ministry of Finance), Direction } \\
\text { Générale des Impots - tax agency } \\
\text { (DGI), PSRF (Forest Revenue } \\
\text { Security Programme), CIME (Taxation } \\
\text { Centre for Medium-sized Enterprises) }\end{array}$ & $\mathrm{X}$ & $\sqrt{ }$ & $\sqrt{ }$ & $\mathrm{X}$ & $\sqrt{ }$ & $\mathrm{X}$ \\
\hline MINEPDED & $\mathrm{X}$ & $\sqrt{ }$ & $\sqrt{ }$ & $\mathrm{X}$ & $\sqrt{ }$ & $\mathrm{X}$ \\
\hline MINAS & $\sqrt{ }$ & $\mathrm{X}$ & $\sqrt{ }$ & $\mathrm{X}$ & $\sqrt{ }$ & $\mathrm{X}$ \\
\hline $\begin{array}{l}\text { MINADER (Ministry of Agriculture and } \\
\text { Rural Development) }\end{array}$ & $\mathrm{X}$ & $\sqrt{ }$ & $?$ & $\sqrt{ }$ & $\mathrm{X}$ & $\sqrt{ }$ \\
\hline $\begin{array}{l}\text { MINATD (Ministry of Territorial } \\
\text { Administration and Decentralisation) }\end{array}$ & $\mathrm{X}$ & $\sqrt{ }$ & $\sqrt{ }$ & $\mathrm{X}$ & $\sqrt{ }$ & $\bar{X}$ \\
\hline $\begin{array}{l}\text { MINEE (Ministry of Energy and Water } \\
\text { Resources) }\end{array}$ & $\mathrm{X}$ & $\sqrt{ }$ & - & - & - & \\
\hline $\begin{array}{l}\text { IRAD (Institute of Agricultural } \\
\text { Research for Development) }\end{array}$ & $\mathrm{X}$ & $\sqrt{ }$ & $\sqrt{ }$ & $\bar{X}$ & $\sqrt{ }$ & $\bar{X}$ \\
\hline SGS & $\sqrt{ }$ & $\sqrt{ }$ & $\sqrt{ }$ & $\mathrm{X}$ & $\sqrt{ }$ & $\mathrm{X}$ \\
\hline Councils & $\mathrm{X}$ & $\sqrt{ }$ & $\sqrt{ }$ & $\mathrm{X}$ & $\sqrt{ }$ & $\bar{X}$ \\
\hline Communities/villages & $\sqrt{ }$ & $\mathrm{X}$ & $\sqrt{ }$ & $\bar{X}$ & $\sqrt{ }$ & $\bar{X}$ \\
\hline Private logging concessions & $\mathrm{X}$ & $\sqrt{ }$ & $\mathrm{X}$ & $\sqrt{ }$ & $\mathrm{X}$ & $\sqrt{ }$ \\
\hline $\begin{array}{l}\text { Association of timber factory owners } \\
\text { and workers }\end{array}$ & $\mathrm{X}$ & $\sqrt{ }$ & $\bar{X}$ & $\sqrt{ }$ & $\mathrm{X}$ & $\sqrt{ }$ \\
\hline Timber associations & $\mathrm{X}$ & $\sqrt{ }$ & $\mathrm{X}$ & $\sqrt{ }$ & $\mathrm{X}$ & $\sqrt{ }$ \\
\hline Transnational corporations (TNCs) & $\mathrm{X}$ & $\sqrt{ }$ & $\mathrm{X}$ & $\sqrt{ }$ & $\mathrm{X}$ & $\sqrt{ }$ \\
\hline Landowners & $\mathrm{X}$ & $\sqrt{ }$ & $?$ & $\sqrt{ }$ & $\sqrt{ }$ & $\bar{X}$ \\
\hline Donors & $\sqrt{ }$ & $\mathrm{X}$ & $\sqrt{ }$ & $\mathrm{X}$ & $\sqrt{ }$ & $\mathrm{X}$ \\
\hline International NGOs/media & $\sqrt{ }$ & $\mathrm{X}$ & $\sqrt{ }$ & $\mathrm{X}$ & $\sqrt{ }$ & $\mathrm{X}$ \\
\hline National NGOs, CSOs, media & $\sqrt{ }$ & $\mathrm{X}$ & $\sqrt{ }$ & $\mathrm{X}$ & $\sqrt{ }$ & $\mathrm{X}$ \\
\hline Media & $\sqrt{ }$ & $\mathrm{X}$ & $\sqrt{ }$ & $\mathrm{X}$ & $\sqrt{ }$ & $\mathrm{X}$ \\
\hline
\end{tabular}

Central government stakeholders are likely to prefer high REDD+ finance scenarios. There are two potential exceptions. First, ministries in competition with those responsible for REDD+ implementation. The main example here is the Ministry of Forests and Wildlife (MINFOF), which would further lose ground to the Ministry of Environment, Nature Protection and Sustainable Development (MINEPDED) under a high finance national scenario. The second exception is sectors that may be in competition with REDD+ over land use, particularly the Ministry of Agriculture, which could see potential agricultural land used for REDD+, negatively affecting its interests. The strength of this effect will be determined by the relative value of REDD+ finance. Where this is high, forestry and other land uses such as agriculture could be displaced by REDD+, negatively affecting the relevant ministries. 
The situation for decentralised entities is clearer. While they would potentially benefit from all high REDD+ finance scenarios, the actual impact on councils and communities would also be affected by benefit sharing arrangements and coverage. Where relative REDD+ finance is high, this raises the possibility that REDD+ could displace other land uses, but only under scenarios where REDD+ is extended beyond current protected areas to those with commercial uses. Where this is the case, the impact on councils/communities would be determined by whether the benefit sharing arrangements are more generous under REDD+ than has been the case under the existing land use (e.g. forestry or agriculture).

Private sector stakeholders in the forestry sector would be negatively affected by high REDD+ finance scenarios, as this increases the probability that the implementation of REDD+ could reduce the economic activity that they rely on (i.e. formal and informal logging), and therefore their revenues. The situation with landowners is somewhat different, as they have the option of switching to REDD+ financed conservation. They would only benefit from this, however, if the relative returns available from REDD+ were greater than those received from existing land uses.

Generally, donors, NGOs, and CSOs are supportive of REDD+ objectives and so would prefer high finance REDD+ scenarios, as this increases the prospect of these objectives being realised. For donors, the caveat is that this will be influenced by how much they have to finance these programmes. For NGOs and CSOs, this would be contingent on equitable benefit sharing within REDD+ programmes.

Table 5 applies the same approach to domestic scenarios. For reasons of brevity, only one scenario is given in each case - e.g. the alternative to 'extensive coverage' is 'limited coverage'. Predicted impacts on stakeholders in these alternatives would obviously be the opposite of those given here.

Table 5 Stakeholder impacts in Cameroon under domestic scenarios

\begin{tabular}{|c|c|c|c|c|c|c|c|}
\hline Scenarios & 1 & 2 & 3 & 4 & 5 & 6 & 7 \\
\hline & $\begin{array}{l}\text { Extensive } \\
\text { coverage }\end{array}$ & $\begin{array}{l}\text { Effective } \\
\text { MRV }\end{array}$ & $\begin{array}{l}\text { High } \\
\text { participation }\end{array}$ & $\begin{array}{l}\text { Equitable } \\
\text { sharing } \\
\text { of } \\
\text { benefits }\end{array}$ & $\begin{array}{l}\text { National } \\
\text { implement- } \\
\text { ation }\end{array}$ & $\begin{array}{l}\text { Sector } \\
\text { implement- } \\
\text { ation }\end{array}$ & $\begin{array}{l}\text { Use of } \\
\text { existing } \\
\text { channels of } \\
\text { disbursal }\end{array}$ \\
\hline $\begin{array}{l}\text { Prime Minister's } \\
\text { Office/Presidency }\end{array}$ & $?$ & $\sqrt{ }$ & $?$ & $?$ & $\sqrt{ }$ & - & $\sqrt{ }$ \\
\hline MINFOF & $\sqrt{ }$ & $\sqrt{ }$ & $\sqrt{ }$ & $\bar{X}$ & $\sqrt{ }$ & $\sqrt{ }$ & $\sqrt{ }$ \\
\hline $\begin{array}{l}\text { MINFI (DGI, } \\
\text { PSRF, CIME) }\end{array}$ & $?$ & $\sqrt{ }$ & $\sqrt{ }$ & $\bar{X}$ & $\sqrt{ }$ & $\mathrm{X}$ & $\sqrt{ }$ \\
\hline MINEPDED & $\sqrt{ }$ & $\sqrt{ }$ & $?$ & $\bar{X}$ & $\sqrt{ }$ & $\sqrt{ }$ & $\bar{X}$ \\
\hline MINAS & $\sqrt{ }$ & $\sqrt{ }$ & $\sqrt{ }$ & $\sqrt{ }$ & $\sqrt{ }$ & - & - \\
\hline MINADER & $\bar{X}$ & $\sqrt{ }$ & - & - & $\sqrt{ }$ & $\mathrm{X}$ & - \\
\hline MINATD & $\sqrt{1}$ & $\sqrt{ }$ & - & - & $\sqrt{ }$ & - & - \\
\hline MINEE & - & - & - & - & - & - & - \\
\hline IRAD & $\sqrt{ }$ & $\sqrt{ }$ & $\sqrt{ }$ & $\sqrt{ }$ & - & $\mathrm{X}$ & - \\
\hline SGS & $\sqrt{ }$ & $\sqrt{ }$ & $\sqrt{ }$ & $\sqrt{ }$ & - & - & - \\
\hline Councils & $?$ & $\sqrt{ }$ & $\sqrt{ }$ & $\sqrt{ }$ & $\mathrm{X}$ & $?$ & - \\
\hline Communities & $?$ & $?$ & $\sqrt{ }$ & $\sqrt{ }$ & $X$ & $?$ & $X$ \\
\hline $\begin{array}{l}\text { Private logging } \\
\text { concessions }\end{array}$ & $X$ & $?$ & - & - & - & - & - \\
\hline
\end{tabular}




\begin{tabular}{|c|c|c|c|c|c|c|c|}
\hline $\begin{array}{l}\text { Association of } \\
\text { timber factory } \\
\text { owners/workers }\end{array}$ & $\mathrm{X}$ & $?$ & - & - & - & - & - \\
\hline $\begin{array}{l}\text { Timber } \\
\text { associations }\end{array}$ & $\mathrm{X}$ & $?$ & - & - & - & - & - \\
\hline TNCs & $\mathrm{X}$ & $?$ & - & - & - & - & - \\
\hline Landowners & $?$ & $?$ & - & - & - & - & - \\
\hline Donors & $\sqrt{ }$ & $\sqrt{ }$ & $\sqrt{ }$ & $\sqrt{ }$ & $?$ & $?$ & $?$ \\
\hline $\begin{array}{l}\text { International } \\
\text { NGOs/media }\end{array}$ & $\sqrt{ }$ & $\sqrt{ }$ & $\sqrt{ }$ & $\sqrt{ }$ & $?$ & $?$ & $?$ \\
\hline $\begin{array}{l}\text { National NGOs, } \\
\text { media }\end{array}$ & $\sqrt{ }$ & $\sqrt{ }$ & $\sqrt{ }$ & $\sqrt{ }$ & $?$ & $?$ & $?$ \\
\hline Media & $\sqrt{ }$ & $\sqrt{ }$ & $\sqrt{ }$ & $\sqrt{ }$ & $?$ & $?$ & $?$ \\
\hline
\end{tabular}

The first scenario concerns whether REDD+ is limited to existing protected areas or extended to areas currently used for other, commercial activities. It is uncertain what position the Prime Minister (PM)/Presidency might take on this, as the net impact on government finances would be determined by whether this took place under a high- or low-finance REDD+ scenario. For high finance scenarios both would be likely to be in favour. Other government agencies would either see a positive or neutral impact, with the exception of the Ministry of Agriculture, which could see the land available for agriculture reduced.

At the local level, SGS would benefit from a more extensive MRV system, while the impact on councils and communities would depend on whether coverage was extended in high or low finance, and equitable or inequitable scenarios. High coverage, high REDD+ finance and an equitable distribution of benefits would favour these stakeholders, while high coverage, low finance and/or inequitable benefit distribution would not.

All private stakeholders would be negatively affected by extensive coverage, with the potential exception of landowners, depending on REDD+ finance outcomes. Given their support for REDD+, donors, NGOs and CSOs would be likely to be supportive of the extensive coverage scenario.

Most stakeholders have an interest in seeing effective MRV systems in place. The exception would be private stakeholders involved in illegal logging. Similarly, most stakeholders would be positive or neutral about high participation of different stakeholder groups in REDD+ programmes. The position of MINEPDED (the lead REDD+ agency) and the PM/Presidency is more uncertain, however, as greater participation of different actors reduces their own ability to shape the way REDD+ evolves in Cameroon.

Different actors are likely to approach benefit sharing in a similar way. Those that would benefit from a more equitable system (e.g. local councils and communities) would be in favour, while those who would potentially see their own revenues fall as a result would not (e.g. relevant central agencies). The position of the PM/Presidency is unclear, as an equitable system would be positive for the country's reputation internationally, not least as it would be strongly favoured by donors and international NGOs.

Whether REDD+ is implemented at the national or local level will create similar effects. Central agencies would no doubt prefer the former, and local entities the latter. Other stakeholders would either be neutral, or, in the case of donors, NGOs and CSOs and local communities, uncertain. Here, preferences would be shaped by these actors' view on the relative competence and honesty of central versus local implementing agencies, and whether local communities would benefit more or less in each case. 
The final two scenarios would generate similar incentives for incumbent or new actors. If REDD+ is implemented via sector actors (i.e. those involved in forestry) then these types of agency would be in favour, and alternative implementing agencies opposed. Similarly, if funds are disbursed through the same channels as existing forest finance, incumbents would be in favour and alternative agencies opposed. The assessment of donors, NGOs and communities is the same as in the previous scenario.

\subsubsection{Ghana}

Table 6 describes the potential impacts of global scenarios on stakeholders in Ghana. As in Cameroon, governance conditionality would be likely to be opposed by central government agencies. Whether the Forestry Commission would take a similar stance is unclear. For traditional authorities and forest communities, impacts would depend upon whether improved governance outcomes benefited them more than the costs of preventing other informal activities. For the private sector, we would expect neutral impacts, with the exception of chainsaw operators. NGOs and donors are supportive of improved forest governance, and therefore would support conditions that achieved this.

Table 6 Stakeholder impacts in Ghana under global scenarios

\begin{tabular}{|c|c|c|c|}
\hline Scenario & 1 & 2 & 3 \\
\hline & $\begin{array}{l}\text { Governance } \\
\text { conditionality }\end{array}$ & $\begin{array}{l}\text { High REDD+ } \\
\text { finance (national) }\end{array}$ & $\begin{array}{l}\text { High relative REDD+ } \\
\text { finance (per unit) }\end{array}$ \\
\hline Ministry of Lands and Natural Resources (MLNR) & $\mathrm{X}$ & $\sqrt{ }$ & $\sqrt{ }$ \\
\hline $\begin{array}{l}\text { Ministry of Environment, Science, Technology and } \\
\text { Innovation (MESTI) Climate Change Centre }\end{array}$ & $\mathrm{X}$ & - & \\
\hline $\begin{array}{l}\text { Ministry of Finance and Economic Planning } \\
\text { (MOFEP) }\end{array}$ & $\mathrm{X}$ & $\sqrt{ }$ & $\sqrt{ }$ \\
\hline Forestry Commission (FC) & $?$ & $\sqrt{ }$ & $\sqrt{ }$ \\
\hline Forest Service Division (FSD), FC & $?$ & $\sqrt{ }$ & $\sqrt{ }$ \\
\hline Timber Industry Development Division (TIDD), FC & $?$ & $\bar{X}$ & $\bar{X}$ \\
\hline Administrator of stool lands & - & - & - \\
\hline Metropolitan, municipal and district assemblies & - & $?$ & $?$ \\
\hline Forest forums & $?$ & - & - \\
\hline Traditional authorities & $?$ & $?$ & $?$ \\
\hline Forest communities & $?$ & $?$ & $?$ \\
\hline Ghana Timber Millers' Organization (GTMO) & - & $\bar{X}$ & $\bar{X}$ \\
\hline $\begin{array}{l}\text { Domestic Lumber Trade Association of Ghana } \\
\text { (DOLTA) }\end{array}$ & - & $\bar{X}$ & $\bar{X}$ \\
\hline Wood Workers Association & - & $\bar{X}$ & $\bar{X}$ \\
\hline Chainsaw operators & $\mathrm{X}$ & $\bar{X}$ & $\bar{X}$ \\
\hline NGOs & $\sqrt{ }$ & $\sqrt{ }$ & $\sqrt{ }$ \\
\hline Donors & $\sqrt{ }$ & $\sqrt{ }$ & $\sqrt{ }$ \\
\hline
\end{tabular}

For central government, high REDD+ finance at the national level would positively affect agencies that are involved with REDD+ implementation (MLNR and FC), and those responsible for government budgets (MOFEP), while negatively affecting agencies that have been kept out of the process (MESTI). Impacts on local agencies are contingent upon the approach to benefit sharing.

Impacts in this regard will be partly shaped by the third scenario: the relative value of REDD+ finance compared with other land uses (including the export sector as discussed for Cameroon). If REDD+ finance per unit of carbon is high enough to compete with other land uses, then it will positively affect stakeholders whose interests are aligned with REDD+ 
objectives (MLNR, FC, donors and NGOs), and negatively affect private sector stakeholders whose commercial interests could be threatened (i.e. the strength of these impacts would be determined by how extensive REDD+ coverage is in practice).

Table 7 examines the impact of this coverage issue, as well as other domestic scenarios in Ghana. For extensive REDD+ coverage, the interests of the FC's Timber Industry Development Division (TIDD) are aligned with these stakeholders, creating similar effects. While the Forestry Commission, donors and NGOs would be expected to favour this scenario, the impact on other stakeholders would depend on the factors considered above, particularly how REDD+ revenues compare with other sources of income (e.g. shares of forest taxes) and how equitably the new revenues are distributed.

As in Cameroon, actors who benefit from illegal activities would oppose an effective MRV system. Chainsaw operators are the clearest example but are unlikely to be the only one.

Table 7 Stakeholder impacts in Ghana under domestic scenarios

\begin{tabular}{|c|c|c|c|c|c|c|c|}
\hline Scenarios & 1 & 2 & 3 & 4 & 5 & 6 & 7 \\
\hline & $\begin{array}{l}\text { Extensive } \\
\text { coverage }\end{array}$ & $\begin{array}{l}\text { Effective } \\
\text { MRV }\end{array}$ & $\begin{array}{l}\text { High } \\
\text { participation }\end{array}$ & $\begin{array}{l}\text { Equitable } \\
\text { sharing } \\
\text { of } \\
\text { benefits }\end{array}$ & $\begin{array}{l}\text { National } \\
\text { implementation }\end{array}$ & $\begin{array}{l}\text { Sector } \\
\text { implementation }\end{array}$ & $\begin{array}{l}\text { Use of } \\
\text { existing } \\
\text { channels } \\
\text { of } \\
\text { disbursal }\end{array}$ \\
\hline MLNR & $?$ & $\sqrt{ }$ & $?$ & $?$ & $\sqrt{ }$ & $\sqrt{ }$ & $\sqrt{ }$ \\
\hline MESTI & $?$ & $?$ & $?$ & - & $\sqrt{ }$ & $\bar{X}$ & - \\
\hline MOFEP & $?$ & $\sqrt{ }$ & $?$ & $\mathrm{X}$ & $\sqrt{ }$ & $\mathrm{X}$ & $\sqrt{ }$ \\
\hline FC & $\sqrt{ }$ & $\sqrt{ }$ & $\sqrt{ }$ & $?$ & $\sqrt{ }$ & $\sqrt{ }$ & $\sqrt{ }$ \\
\hline FC (FSD) & $\sqrt{ }$ & $\sqrt{ }$ & $\sqrt{ }$ & $?$ & $\sqrt{ }$ & $\sqrt{ }$ & $\sqrt{ }$ \\
\hline$\overline{F C ~(T I D D) ~}$ & $\mathrm{X}$ & $\sqrt{ }$ & - & $?$ & $\sqrt{ }$ & $\sqrt{ }$ & $\sqrt{ }$ \\
\hline $\begin{array}{l}\text { Administrator } \\
\text { of stool lands }\end{array}$ & - & - & - & - & $\mathrm{X}$ & - & - \\
\hline $\begin{array}{l}\text { Local } \\
\text { assemblies }\end{array}$ & $?$ & $\sqrt{ }$ & $\sqrt{ }$ & $\sqrt{ }$ & $\mathrm{X}$ & - & $?$ \\
\hline $\begin{array}{l}\text { Forest } \\
\text { forums }\end{array}$ & $?$ & $\sqrt{ }$ & $\sqrt{ }$ & $\sqrt{ }$ & - & - & - \\
\hline $\begin{array}{l}\text { Traditional } \\
\text { authorities } \\
\end{array}$ & $?$ & $?$ & $\sqrt{ }$ & $\sqrt{ }$ & $?$ & $?$ & $?$ \\
\hline Communities & $?$ & $?$ & $\sqrt{ }$ & $\sqrt{ }$ & $?$ & $?$ & $?$ \\
\hline GTMO & $\bar{X}$ & $?$ & - & - & - & - & - \\
\hline$\overline{\text { DOLTA }}$ & 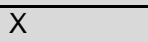 & $?$ & - & - & - & - & - \\
\hline $\begin{array}{l}\text { Wood } \\
\text { Workers } \\
\text { Association }\end{array}$ & $\bar{X}$ & $?$ & - & - & - & - & - \\
\hline $\begin{array}{l}\text { Chainsaw } \\
\text { operators }\end{array}$ & $\bar{X}$ & $\mathrm{X}$ & $?$ & $?$ & - & - & - \\
\hline NGOs & $\sqrt{ }$ & $\sqrt{ }$ & $\sqrt{ }$ & $\sqrt{ }$ & $?$ & $?$ & $?$ \\
\hline Donors & $\sqrt{ }$ & $\sqrt{ }$ & $\sqrt{ }$ & $\sqrt{ }$ & $?$ & $?$ & $?$ \\
\hline
\end{tabular}

Local stakeholders would benefit from more participation and from the more equitable benefit sharing systems that would be likely to result. Actors in favour of these goals (donors and NGOs, and the FC generally) would also benefit, while central agencies could see their influence and control diluted.

Central agencies would favour national implementation of REDD+, and local agencies the opposite. Other groups would either be unaffected (private sector) or the impact would depend on which form most favoured their interests. The impact of the last two scenarios would be similarly determined. The perspective of donors, NGOs and communities on 
whether current or new forms of disbursal are preferable, for example, would be shaped by their views on the current system and the proposed replacement.

\subsubsection{Sierra Leone}

Table 8 examines potential stakeholder impacts from global scenarios in Sierra Leone. For central government agencies, the impact of governance conditionality (which we take to be effective) is mixed. As in other countries, we assume this is negative for the Head of State and central ministries, as conditionality reduces their freedom to operate, and - other things being equal - would be opposed.

Table 8 Stakeholder impacts in Sierra Leone under global scenarios

\begin{tabular}{|c|c|c|c|}
\hline & $\begin{array}{l}\text { Governance } \\
\text { conditionality }\end{array}$ & $\begin{array}{l}\text { High REDD+ finance } \\
\text { (national) }\end{array}$ & $\begin{array}{l}\text { High relative REDD+ } \\
\text { finance (per unit) }\end{array}$ \\
\hline Office of the President & $\mathrm{X}$ & $\sqrt{ }$ & $\sqrt{ }$ \\
\hline Parliament & $\sqrt{ }$ & $\sqrt{ }$ & $\sqrt{ }$ \\
\hline National Protected Area Authority (NPAA) & $\sqrt{ }$ & $\sqrt{ }$ & $\sqrt{ }$ \\
\hline Forestry Division (FD) & $\mathrm{X}$ & $\mathrm{X}$ & $\mathrm{X}$ \\
\hline Environmental Protection Agency (EPA) & $\sqrt{ }$ & $\sqrt{ }$ & $\sqrt{ }$ \\
\hline $\begin{array}{l}\text { MOFED (Ministry of Finance and Economic } \\
\text { Development)/NRA (National Revenue Authority) }\end{array}$ & $\mathrm{X}$ & $\sqrt{ }$ & $\sqrt{ }$ \\
\hline $\begin{array}{l}\text { Ministry of Agriculture, Forestry and Food } \\
\text { Security (MAFFS) }\end{array}$ & $\bar{X}$ & $\mathrm{X}$ & $\mathrm{X}$ \\
\hline Ministry of Lands & $\mathrm{X}$ & $\mathrm{X}$ & $\mathrm{X}$ \\
\hline Ministry of Tourism & $\mathrm{X}$ & $\sqrt{ }$ & $\sqrt{ }$ \\
\hline Ministry of Trade & $\bar{X}$ & $\mathrm{X}$ & $\mathrm{X}$ \\
\hline Ministry of Transport & $\mathrm{X}$ & $\mathrm{X}$ & $\mathrm{X}$ \\
\hline Law enforcement officers & $?$ & $?$ & $?$ \\
\hline Municipal and local government & $?$ & $?$ & $?$ \\
\hline Traditional leaders & $?$ & $?$ & $?$ \\
\hline Community members & $?$ & $?$ & $?$ \\
\hline Timber associations & $\mathrm{X}$ & $?$ & $\mathrm{X}$ \\
\hline TNCs (Miro Forestry company) & $\sqrt{ }$ & $?$ & $\mathrm{X}$ \\
\hline Union of Timber Factory Owners & $\mathrm{X}$ & $?$ & $\mathrm{X}$ \\
\hline Chainsaw operators/association & $\mathrm{X}$ & $?$ & $\mathrm{X}$ \\
\hline Landowners & $?$ & $?$ & $?$ \\
\hline Donors & $\sqrt{ }$ & $\sqrt{ }$ & $\sqrt{ }$ \\
\hline International NGOs & $\sqrt{ }$ & $\sqrt{ }$ & $\sqrt{ }$ \\
\hline Local NGOs & $\sqrt{ }$ & $\sqrt{ }$ & $\sqrt{ }$ \\
\hline
\end{tabular}

In contrast, we assume that the impact on environmental agencies (NPAA and EPA) would be positive, as these scenarios would increase their ability to achieve their environmental objectives. The impact on law enforcement agencies is uncertain. Better governance would enable them to operate more effectively, but would also reduce the scope of their benefiting from illegal payments. The net impact - in terms of incentives - would therefore depend on the weight of corrupt actors.

The impact on local stakeholders is uncertain. As with law enforcement, the net effect will depend on the proportion of each stakeholder group benefiting from illegal activities in the forestry sector. If this is relatively low, then improved governance would create net benefits, and vice versa. 
To the extent that private sector actors benefit from the status quo, we assume most would see negative impacts from better governance - at least in the short term. Exceptions are TNCs (i.e. the Miro Forestry Company), which would benefit from a more robust governance regime. The current forest governance regime does not favour them as they continue having to pay traditional leaders and landowners despite having paid the official land leases. This company's view is that if reforms are introduced as a result of REDD+, this will lead to improved community forest governance, which will benefit them. In terms of REDD+ scenarios, the view of the company's Managing Director is that REDD+ will focus on reserved forest areas and not on community forests, where they have an interest.

For REDD+ finance, central agencies would benefit from high national level financing, with the exception of those that are potentially in competition for land use (e.g. Ministry of Agriculture; Forestry Division) or could see a reduction in commercial activity as a result of REDD+ (e.g. Transport and Trade). The impacts on local agencies depend on the extent to which they benefit from this financing, either through benefit-sharing mechanisms or through allocations between central and local government. They are thus dependent on other REDD+ scenarios, as discussed below.

The impact on private operators would be similarly contingent, with the most important determinants being whether REDD+ coverage was extended into areas currently used commercially (i.e. community forests), and whether the value of REDD+ finance (per unit of carbon) was high enough to enable REDD+ to compete with other commercial activities. This is reflected in the final scenario, where the private sector impacts of high relative REDD+ finance are negative. While also uncertain, the situation with landowners is rather different, as they could benefit under extensive coverage/high relative REDD+ finance scenarios through higher returns on their land than under current alternatives.

The final table in this section looks at stakeholder impacts in Sierra Leone in areas decided domestically. For REDD+ coverage we see the now familiar pattern, where agencies that are supportive of REDD+ objectives are likely to benefit (NPAA; EPA; donors and NGOs), whilst those whose commercial interests could be adversely affected (private operators), or whose political influence could suffer (competitor ministries) would see the opposite impacts.

Impacts on other stakeholders are uncertain. The impact on Parliament, for example, would depend on the effect of extended coverage on the constituencies of members of parliament, which would be a function of the approach to benefit sharing, as well as whether high or low REDD+ finance results. The impact on the MOFED of extended coverage would also be determined by REDD+ finance scenarios. Where both are high, extensive coverage could lead to a net increase in revenues, benefiting the MOFED. Where low finance scenarios combine with extensive coverage, however, revenues would fall.

The Ministry of Agriculture, Forests and Food Security (MAFFS) is an interesting example. MAFFS would benefit from high finance, extensive REDD+ coverage scenarios, as it oversees the implementing agencies. It could also suffer, however, if REDD+ expansion reduced the scope for other, commercial activities that it is responsible for. The net impact would depend on the balance of these economic costs and benefits, and the actors for and against each of these within the ministry.

The impact on local actors would be determined by the finance scenarios discussed above i.e. whether they benefit from these to a greater extent than is the case under current arrangements. 
Table 9 Stakeholder impacts in Sierra Leone under domestic scenarios

\begin{tabular}{|c|c|c|c|c|c|c|c|}
\hline & $\begin{array}{l}\text { Extensive } \\
\text { coverage }\end{array}$ & $\begin{array}{l}\text { Effective } \\
\text { MRV }\end{array}$ & $\begin{array}{l}\text { High } \\
\text { participation }\end{array}$ & $\begin{array}{l}\text { Equitable } \\
\text { sharing } \\
\text { of } \\
\text { benefits }\end{array}$ & $\begin{array}{l}\text { National } \\
\text { implementation }\end{array}$ & $\begin{array}{l}\text { Sector } \\
\text { implementation }\end{array}$ & $\begin{array}{l}\text { Use of } \\
\text { existing } \\
\text { channels } \\
\text { of } \\
\text { disbursal }\end{array}$ \\
\hline $\begin{array}{l}\text { Office of the } \\
\text { President }\end{array}$ & $\sqrt{ }$ & $\sqrt{ }$ & $\sqrt{ }$ & $\sqrt{ }$ & $\sqrt{ }$ & $\mathrm{X}$ & $\sqrt{ }$ \\
\hline Parliament & $?$ & $?$ & $\sqrt{ }$ & $\sqrt{ }$ & $?$ & $?$ & $?$ \\
\hline NPAA & $\sqrt{ }$ & $\sqrt{ }$ & $\sqrt{ }$ & $\sqrt{ }$ & $\sqrt{ }$ & $\sqrt{ }$ & $\sqrt{ }$ \\
\hline FD & $\sqrt{ }$ & $\sqrt{ }$ & - & $?$ & $\sqrt{ }$ & $\sqrt{ }$ & $\sqrt{ }$ \\
\hline EPA & $\sqrt{ }$ & $\sqrt{ }$ & $\sqrt{ }$ & $?$ & $\sqrt{ }$ & - & - \\
\hline MOFED/NRA & $?$ & $\sqrt{ }$ & - & $\mathrm{X}$ & $\sqrt{ }$ & $\mathrm{X}$ & - \\
\hline MAFFS & $?$ & $?$ & - & - & $\sqrt{ }$ & $\sqrt{ }$ & $\sqrt{ }$ \\
\hline $\begin{array}{l}\text { Ministry of } \\
\text { Lands }\end{array}$ & $\mathrm{X}$ & $\mathrm{X}$ & - & - & $\sqrt{ }$ & $\mathrm{X}$ & $\sqrt{ }$ \\
\hline $\begin{array}{l}\text { Ministry of } \\
\text { Tourism }\end{array}$ & $\sqrt{ }$ & $\sqrt{ }$ & - & - & $\sqrt{ }$ & $\sqrt{ }$ & - \\
\hline $\begin{array}{l}\text { Ministry of } \\
\text { Trade }\end{array}$ & $\mathrm{X}$ & $\mathrm{X}$ & - & - & $\sqrt{ }$ & $\mathrm{X}$ & - \\
\hline $\begin{array}{l}\text { Ministry of } \\
\text { Transport }\end{array}$ & $\bar{X}$ & $\mathrm{X}$ & - & - & $\sqrt{ }$ & $\mathrm{X}$ & - \\
\hline $\begin{array}{l}\text { Law } \\
\text { enforcement } \\
\text { officers }\end{array}$ & $?$ & $?$ & - & $\sqrt{ }$ & $\sqrt{ }$ & - & - \\
\hline $\begin{array}{l}\text { Municipal and } \\
\text { local } \\
\text { government }\end{array}$ & $?$ & $?$ & - & $\sqrt{ }$ & $\bar{X}$ & $\mathrm{X}$ & $\sqrt{ }$ \\
\hline $\begin{array}{l}\text { Traditional } \\
\text { leaders }\end{array}$ & $?$ & $?$ & $\sqrt{ }$ & $\sqrt{ }$ & $\mathrm{X}$ & $\sqrt{ }$ & $?$ \\
\hline $\begin{array}{l}\text { Community } \\
\text { members }\end{array}$ & $?$ & $?$ & $\sqrt{ }$ & $\sqrt{ }$ & $?$ & $\sqrt{ }$ & $?$ \\
\hline $\begin{array}{l}\text { Timber } \\
\text { associations }\end{array}$ & $\mathrm{X}$ & $\bar{X}$ & - & $?$ & - & - & - \\
\hline $\begin{array}{l}\text { TNCs (Miro } \\
\text { forestry } \\
\text { company) }\end{array}$ & $\mathrm{X}$ & $\sqrt{ }$ & - & $?$ & - & - & - \\
\hline $\begin{array}{l}\text { Union of timber } \\
\text { factory owners }\end{array}$ & $\mathrm{X}$ & - & - & $?$ & - & - & - \\
\hline $\begin{array}{l}\text { Chainsaw } \\
\text { operators/ } \\
\text { association }\end{array}$ & $\mathrm{X}$ & $\mathrm{X}$ & - & $?$ & - & - & - \\
\hline Landowners & $?$ & $\sqrt{ }$ & - & $?$ & $?$ & $?$ & $?$ \\
\hline Donors & $\sqrt{ }$ & $\sqrt{ }$ & $\sqrt{ }$ & $\sqrt{ }$ & $?$ & $?$ & $?$ \\
\hline $\begin{array}{l}\text { International } \\
\text { NGOs }\end{array}$ & $\sqrt{ }$ & $\sqrt{ }$ & $\sqrt{ }$ & $\sqrt{ }$ & $?$ & $?$ & $?$ \\
\hline Local NGOs & $\sqrt{ }$ & $\sqrt{ }$ & $\sqrt{ }$ & $\sqrt{ }$ & $?$ & $?$ & $?$ \\
\hline
\end{tabular}

The distribution of impacts of a good MRV system are almost identical, and for similar reasons. One exception is that larger forestry companies (i.e. the Miro Company) would benefit from a more effective system of MRV, as they are more able to comply.

Local stakeholders would benefit under a high participation scenario, as would the parliamentarians who represent them. Agencies charged with implementing REDD+ objectives would also favour this scenario as it might increase their ability to achieve these objectives. Donors and NGOs would be similarly affected. Most other agencies would not be greatly affected by this scenario.

For benefit sharing, we again contrast those who stand to benefit (e.g. local stakeholders) with those who could lose (e.g. central stakeholders whose share of REDD+ revenues could fall if they are more widely disbursed). The impact on private actors is here seen as 
uncertain, as it is possible - if unlikely - that these actors could be recipients of REDD+ finance.

Finally, the impacts of implementation and disbursement scenarios differ between stakeholders that benefit from the status quo (i.e. those currently for disbursing forest finance), or those who would benefit from national versus local implementation (i.e. central versus local governance agencies).

Having considered how REDD+ implementation could affect the interests of different stakeholders, the next section examines the mechanisms through which these could influence forest tax outcomes.

\subsection{From behaviours to forest tax outcomes}

Previously, six potential objectives of forest tax systems were identified: revenue raising; sustainable forest management (SFM); equitable sharing of forest taxes; promotion of domestic industries; support for sustainable livelihoods; and good governance. In this section we explore how stakeholders could potentially influence these outcomes, before considering the role that policy could play.

\subsubsection{Central government stakeholders}

Table 10 links central government stakeholders to each objective. As the channels of impact are similar, this is presented generically, rather than being specific to each country. Of course, the division of responsibilities will vary between the countries, as will the specific agencies involved in particular cases. However, there is enough commonality for a general picture to emerge. An important area of difference, however, is on the degree of influence of different actors. This is considered in the following section on policy, where we explore how policy could affect the six potential outcomes.

Depending on the degree of central control, the PM/Presidency has ultimate responsibility for decisions in each category. These range from deciding whether to sign international agreements on environmental or governance issues, to taking strategic decisions on the scale and form of commercial forestry within the country, the role of domestic industry and strategic land use in long-term development, and how all of these issues relate to areas that are protected for environmental reasons. The PM/President sets the tone on governance, and monitors and enforces behaviour on these issues.

Finance ministries are the next most important actors in most countries, though they are not responsible for collecting forest taxes in our case study countries. Finance ministries do set the tone for the general attitude towards tax collection though, which will filter down to collecting agencies. For other outcome areas, ministries of finance affect policy through their influence on the PM/President, but can also block policies by withholding budget approval. Where tax objectives could negatively affect government revenues - if large areas are classified as protected areas, leading to a reduction in revenues from commercial activities, for example, or forest taxes are widely and 'equitably' distributed - the finance ministry could potentially block such moves.

The next category of stakeholders are relevant sector ministries (environment, land, natural resources, forestry etc.) or sub-ministerial, implementing agencies (e.g. the Forestry Commission in Ghana or the NPAA in Sierra Leone). Below the strategic level, these are the most influential actors with respect to forest tax outcomes. They are responsible for allocating concessions, setting rates and collecting taxes, and will either control or strongly influence land use decisions, including the categorisation of protected areas. In conjunction with enforcement agencies, these stakeholders are also responsible for monitoring and 
compliance. These activities exert a strong influence over forest tax outcomes, and the degree to which they are performed effectively and fairly does much to shape governance.

Table 10 Forest tax objectives/outcomes and central stakeholder behaviours

\begin{tabular}{|c|c|c|}
\hline Stakeholders & Forest tax outcomes & Relevant behaviours \\
\hline \multirow[t]{6}{*}{ President/PM } & Revenue raising & $\begin{array}{l}\text { Influence policy on forestry activity, including scope of protected areas } \\
\text { and strategic land use decisions }\end{array}$ \\
\hline & SFM & Decide whether to sign and implement international agendas \\
\hline & Equitable tax share & Influence/shape policy \\
\hline & Domestic industry & Influence/shape policy \\
\hline & $\begin{array}{l}\text { Sustainable } \\
\text { livelihoods }\end{array}$ & Influence/shape policy \\
\hline & Good governance & Set example, establish initiatives, monitor and enforce \\
\hline \multirow[t]{6}{*}{ Finance ministry } & Revenue raising & Design and initiate policy. May collect taxes \\
\hline & SFM & Can block policies (budget approval) and influence President/PM \\
\hline & Equitable tax share & Can design, influence or block policy \\
\hline & $\begin{array}{l}\text { Domestic industry } \\
\text { promotion }\end{array}$ & Can design, influence or block policy \\
\hline & $\begin{array}{l}\text { Sustainable } \\
\text { livelihoods }\end{array}$ & Can design, influence or block policy \\
\hline & Good governance & Monitoring budgets and auditing of ministry/agency activities \\
\hline \multirow[t]{6}{*}{$\begin{array}{l}\text { Environment, } \\
\text { resources, land and } \\
\text { forestry ministries }\end{array}$} & Revenue raising & $\begin{array}{l}\text { May collect taxes. Can set rates and establish scope of protected } \\
\text { areas, and level and form of protected areas. May influence/control } \\
\text { land use more generally }\end{array}$ \\
\hline & SFM & $\begin{array}{l}\text { Monitoring and enforcement. Design, initiate and implement policy and } \\
\text { engage in international discussions/agreements }\end{array}$ \\
\hline & Equitable tax share & Can influence policy design \\
\hline & Domestic industry & Can influence supply of timber \\
\hline & $\begin{array}{l}\text { Sustainable } \\
\text { livelihoods }\end{array}$ & Design, initiate and implement policy \\
\hline & Good governance & Set example, establish initiatives and capacity building \\
\hline \multirow{6}{*}{$\begin{array}{l}\text { Sub-ministerial } \\
\text { agencies }\end{array}$} & Revenue raising & May collect taxes. Can set rates and establish protected areas \\
\hline & SFM & Monitoring/enforcement. Design, initiate and implement policy \\
\hline & Equitable tax share & Can influence policy design \\
\hline & Domestic industry & Can restrict supply of timber \\
\hline & $\begin{array}{l}\text { Sustainable } \\
\text { livelihoods }\end{array}$ & Design, initiate and implement policy \\
\hline & Good governance & Set example, establish initiatives and capacity building \\
\hline \multirow[t]{6}{*}{ 'Competing ministries' } & Revenue raising & $\begin{array}{l}\text { Can work with TNCs to promote trade, commercial forestry generally, } \\
\text { or ecotourism }\end{array}$ \\
\hline & SFM & Can be involved in establishing international standards \\
\hline & Equitable tax share & Not involved \\
\hline & Domestic industry & Supporting and promoting export sectors \\
\hline & $\begin{array}{l}\text { Sustainable } \\
\text { livelihoods }\end{array}$ & Not involved \\
\hline & Good governance & Not involved \\
\hline \multirow[t]{6}{*}{ Law enforcement } & Revenue raising & Enforce compliance and punish offenders \\
\hline & SFM & Enforce compliance and punish offenders \\
\hline & Equitable tax share & Prosecute corruption (i.e. diversion of resources) \\
\hline & Domestic industry & Not involved \\
\hline & $\begin{array}{l}\text { Sustainable } \\
\text { livelihoods }\end{array}$ & Not involved \\
\hline & Good governance & Investigate and prosecute corruption \\
\hline
\end{tabular}


'Competing' ministries and agencies are those whose interests are served by a high valueadding domestic forestry sector rather than the implementation of REDD+ across the country. Consequently, they are likely to encourage those elements within implementing agencies that are supportive of these goals, and lobby at higher levels of government to this effect. The relative power of these stakeholders compared to REDD+ agencies is thus likely to be very important in determining which REDD+ scenarios emerge.

The final sector of actors to consider are law enforcement agencies, the behaviour of which is crucial for outcomes in most of the areas considered, particularly those relating to compliance and governance.

\subsubsection{Local stakeholders}

Table 11 applies the same approach to local stakeholders. The first category is local, district or municipal councils. Generally, these have some responsibility for revenues and monitoring and compliance, and can therefore directly affect revenues raised. While they may have similar formal objectives to the central government stakeholders with respect to monitoring SFM, incentives are less strong as this does not generate revenues from which they benefit. The implementation of REDD+ has the potential to change this.

These actors are not generally involved in determining how taxes are shared amongst stakeholders, or the development of domestic industry. In contrast, local councils may work with local NGOs to develop new forms of sustainable livelihoods, which may be a condition of NGO funding in this area.

As with central government agencies, local councils have a key governance role to play in terms of the example they set. They can also affect governance through their influence over traditional leaders.

Traditional authorities have a strong influence over revenue raising and SFM in their areas. As well as directly influencing whether certain fees are paid, they can either encourage IFAs by turning a blind eye to illegal logging (and profiting from this), or prevent illegal operators from using their lands. They are thus also key local actors with respect to good governance. They are also the main stakeholders promoting equitable benefit sharing for local communities and may work with NGOs to develop and promote sustainable livelihoods.

Table 11 Forest tax objectives/outcomes and local stakeholder behaviours

\begin{tabular}{|l|l|l|}
\hline Stakeholders & Forest tax outcomes & Relevant behaviours \\
\hline Local councils & Revenue & Collect some forest revenues; monitor/enforce compliance \\
\hline & SFM & $\begin{array}{l}\text { May manage local/community forest; prevent IFAs; promote reforestation; } \\
\text { may use procurement to support legal timber }\end{array}$ \\
\hline & Equitable tax & Not involved \\
\hline & Domestic industry & Not involved \\
\hline & Sustainable livelihoods & Can work with NGOs to develop (may be funding condition) \\
\hline $\begin{array}{l}\text { Traditional } \\
\text { authorities }\end{array}$ & Good governance & $\begin{array}{l}\text { Can demand accountability from traditional leaders, and manage internal } \\
\text { resources effectively (or not) }\end{array}$ \\
\hline & Revenue raising & $\begin{array}{l}\text { Influence payment of forest fees; may allow/prevent illegal operators to } \\
\text { work without paying fees/taxes }\end{array}$ \\
\hline & SFM & $\begin{array}{l}\text { Can allow chainsaw operators to function; can promote reforestation; and } \\
\text { restrict access to culturally important forests }\end{array}$ \\
\hline & Equitable tax share & Advocates for increasing community shares and control \\
\hline & $\begin{array}{l}\text { Domestic industry } \\
\text { promotion }\end{array}$ & $\begin{array}{l}\text { Not involved } \\
\text { promotion }\end{array}$ \\
\hline
\end{tabular}




\begin{tabular}{|l|l|l|}
\hline & Good governance & Sets example (good or bad) \\
\hline Communities & Revenue raising & $\begin{array}{l}\text { Potential to reduce or block logging; can be involved in land-use } \\
\text { conversion and felling trees for charcoal; may benefit from illegal logging, } \\
\text { but best placed to reduce this. Alternatively, can protect illegal operators } \\
\text { by providing cover }\end{array}$ \\
\hline & SFM & Potential to promote/ensure SFM. Providers of labour for illegal activities \\
\hline & Equitable tax share & Promote equitable sharing of benefits \\
\hline & Domestic industry & Potential supply of labour and beneficiaries \\
\hline & Sustainable livelihoods & Potential beneficiaries \\
\hline & Good governance & Can promote or obstruct as described \\
\hline
\end{tabular}

Local communities are also key actors with respect to revenue generation and SFM. They can participate in or tolerate illegal logging, reducing potential revenues, and creating negative environmental impacts. On the positive side, they are also well placed to prevent these activities, by undertaking monitoring activities to promote SFM and governance.

\subsubsection{Private sector stakeholders}

Table 12 looks at the behaviour of private sector stakeholders in relation to forest tax outcomes. TNCs have significant lobbying power, and so have the ability to influence policy, particularly for revenue raising (e.g. tax rates) and SFM (e.g. extent of protected areas and restrictions on commercial logging activities). Some TNCs focus purely on logging for export, while others are more involved in the domestic sector. Their behaviours in this respect are thus an important determinant of outcomes related to domestic industry. Through their employment practices and corporate social responsibility (CSR) activities, TNCs also have a strong influence on the creation and maintenance of 'sustainable livelihoods' (defined to include employment with TNCs). Finally, given their influence and economic weight in the sector, and their approach to tax compliance and bribery, TNCs are one of the most important drivers of good governance.

Table 12 Forest tax objectives/outcomes and private sector stakeholder behaviours

\begin{tabular}{|l|l|l|}
\hline Stakeholders & Forest tax outcomes & Relevant behaviours \\
\hline TNCs & Revenue raising & Can lobby for lower taxes and comply with taxes (or not) \\
\hline & SFM & $\begin{array}{l}\text { Can lobby for weaker policy, adhere to agreements (or not), promote } \\
\text { certification (or not) }\end{array}$ \\
\hline & Equitable tax & Not involved \\
\hline & Domestic industry & Can focus on export sector or promote local industry \\
\hline & $\begin{array}{l}\text { Sustainable } \\
\text { livelihoods }\end{array}$ & $\begin{array}{l}\text { Can support sustainable livelihoods (broadly defined) through } \\
\text { employment and CSR }\end{array}$ \\
\hline Domestic logging \\
firms & Good governance & $\begin{array}{l}\text { Can pay bribes or not; can demand accountability from state institutions } \\
\text { for payments }\end{array}$ \\
\hline & Revenue raising & Can comply or not \\
\hline & SFM & Can adhere to agreements (or not), promote certification (or not) \\
\hline & Equitable tax & Not involved \\
\hline & Domestic industry & $\begin{array}{l}\text { Directly involved as most processing and industry development are } \\
\text { carried out by domestic firms }\end{array}$ \\
\hline & $\begin{array}{l}\text { Sustainable } \\
\text { livelihoods }\end{array}$ & Provide employment and can provide CSR \\
\hline & Good governance & $\begin{array}{l}\text { Can pay bribes or not; can demand accountability from state institutions } \\
\text { for payments }\end{array}$ \\
\hline & Revenue raising & Pay taxes or not. Largely stumpage fees \\
\hline & SFM & $\begin{array}{l}\text { As per concession agreements, may be obliged to replant, limit total } \\
\text { felling and respect restrictions on particular species. Can comply or not }\end{array}$ \\
\hline
\end{tabular}




\begin{tabular}{|c|c|c|}
\hline & Equitable tax share & $\begin{array}{l}\text { Not directly involved, but can push for disbursal to local areas to obtain } \\
\text { support from traditional leaders }\end{array}$ \\
\hline & Domestic industry & $\begin{array}{l}\text { Some are millers and some just log. Latter have little direct impact, but } \\
\text { they may choose to supply local small wood industries, depending on } \\
\text { difference between local and international prices }\end{array}$ \\
\hline & $\begin{array}{l}\text { Sustainable } \\
\text { livelihoods }\end{array}$ & Provide employment and can provide CSR \\
\hline & Good governance & $\begin{array}{l}\text { May (or may not) pay bribes to acquire concessions. May also pay bribes } \\
\text { to forestry officials, police and traditional leaders, and recruit illegal } \\
\text { operators }\end{array}$ \\
\hline \multirow{6}{*}{$\begin{array}{l}\text { Unions/trade } \\
\text { associations }\end{array}$} & Revenue raising & Lobby to reduce tax burdens; can support member compliance \\
\hline & SFM & Can support reforestation and sustainable commercial logging \\
\hline & Equitable tax & Not involved \\
\hline & Domestic industry & Supportive of domestic industries \\
\hline & $\begin{array}{l}\text { Sustainable } \\
\text { livelihoods }\end{array}$ & Employment and CSR \\
\hline & Good governance & Monitor members (at least this is formally the case) \\
\hline \multirow[t]{6}{*}{ Chainsaw operators } & Revenue raising & $\begin{array}{l}\text { Potential loss of fees; potential loss of stumpage (where commercial } \\
\text { logging permitted) }\end{array}$ \\
\hline & SFM & Quantity of logging and selective logging of high value trees \\
\hline & Equitable tax & Not involved \\
\hline & Domestic industry & $\begin{array}{l}\text { Compete (more cheaply) with legal traders to supply timber to local } \\
\text { market; difficult for legal suppliers to compete }\end{array}$ \\
\hline & $\begin{array}{l}\text { Sustainable } \\
\text { livelihoods }\end{array}$ & Source of income for local people \\
\hline & Good governance & Pay bribes to forestry officials, police, traditional leaders \\
\hline
\end{tabular}

Domestic logging firms undertake similar activities but may have less lobbying power. As they supply most of the timber to the local market, they are also key to domestic industrial development, and can promote or prevent the use of legal timber.

Concession holders are also involved in the same activities and thus have similar potential impacts on outcomes. They may pay their taxes, comply with environmental agreements, and provide employment and social benefits to local people as set out in concession agreements. Alternatively, they may seek to avoid or minimise such obligations, including using bribes to facilitate this, or to obtain concessions in the first place. For most forest tax outcomes, therefore, they are key stakeholders.

Broadly, unions and trade associations represent the interests of their members, and so reflect their positions. They may also be charged with monitoring the behaviour of their members, though the extent to which this happens in practice is far from clear. Where they do work actively, however, is in opposing the activities of illegal chainsaw operators, who undermine their members' interests.

As discussed at various points, chainsaw operators are key stakeholders in terms of forest outcomes. Through illegal logging activities they reduce tax revenues and cause deforestation. This has a negative impact on the other outcomes considered, though the payments these operators make to local people and traditional authorities may actually represent a crucial source of income. Whether all these stakeholders can be incentivised to change their behaviour and so improve tax outcomes in these areas depends on the extent to which they can be compensated for the loss in income this would entail. 


\subsubsection{Donors, NGOs and CSOs}

The final table in this section explores how the activities of donors, NGOs/CSOs and researchers affect forest tax outcomes. In the forestry sector, the most influential is the donor community. While these actors are beginning to pay more attention to tax and development issues, to join a long-standing, if weak, support for domestic industry development, their main focus has been on environmental and social issues, as well as governance. Given their influence over government, and central role in implementing REDD+ (and deciding on which global scenarios emerge), these actors are uniquely well-placed to affect policy changes that integrate tax and REDD+ objectives.

Table 13 Forest tax objectives/outcomes and donor and NGO stakeholder behaviours

\begin{tabular}{|c|c|c|}
\hline Stakeholders & Forest tax outcomes & Relevant behaviours \\
\hline \multirow[t]{6}{*}{$\begin{array}{l}\text { Bilateral/multilateral } \\
\text { donors }\end{array}$} & Revenue raising & $\begin{array}{l}\text { Pressure authorities to reform forest laws (e.g. move tax } \\
\text { rates) and enforce compliance }\end{array}$ \\
\hline & SFM & Promote SFM and biodiversity \\
\hline & Equitable tax share & $\begin{array}{l}\text { Can promote an increased share for local communities, } \\
\text { and pressure for compliance }\end{array}$ \\
\hline & Domestic industry & Some promotion of economic development \\
\hline & Sustainable livelihoods & Work with NGOs to promote \\
\hline & Good governance & Conditionality and incentives for good governance \\
\hline \multirow[t]{6}{*}{ INGOS } & Revenue raising & $\begin{array}{l}\text { Support modernised forest laws, but environmental NGOs } \\
\text { and those supporting indigenous people can also be } \\
\text { hostile to logging (and thus revenue generation) }\end{array}$ \\
\hline & SFM & Promote SFM and biodiversity \\
\hline & Equitable tax share & $\begin{array}{l}\text { Promote an increased share for local communities, and } \\
\text { pressure for compliance. }\end{array}$ \\
\hline & Domestic industry & Can reduce timber available through SFM \\
\hline & Sustainable livelihoods & $\begin{array}{l}\text { Strong promoters of non-timber forest product (NFTP) } \\
\text { industries and sustainable livelihoods }\end{array}$ \\
\hline & Good governance & Advocacy for transparency, accountability \\
\hline \multirow[t]{6}{*}{ Domestic NGOs/CSOs } & Revenue raising & $\begin{array}{l}\text { Can pressure government to ensure compliance (Ghana) } \\
\text { but may focus on SFM issues (Sierra Leone) }\end{array}$ \\
\hline & SFM & Primary focus in some countries (Sierra Leone) \\
\hline & Equitable tax share & $\begin{array}{l}\text { Can be important, depending on weight of SFM in their } \\
\text { interests }\end{array}$ \\
\hline & Domestic industry & Can reduce timber available through SFM \\
\hline & Sustainable livelihoods & Promote alternatives to logging in forest areas \\
\hline & Good governance & Advocacy for transparency, accountability \\
\hline Academic/policy & All objectives & $\begin{array}{l}\text { Forestry academics are traditionally focused on natural } \\
\text { science, but 'social forestry' becoming more important } \\
\text { (particularly in Ghana) }\end{array}$ \\
\hline
\end{tabular}

While perhaps less influential on developing country governments - though not always INGOs have similar interests to donors, although with the somewhat different emphases described above. They are also particularly influential on the activities of bilateral and multilateral donors, however, and are thus also a potentially key driver of forest tax/REDD+ integration. This would require engagement with forest tax issues, however, including overcoming the hostility that exists in some quarters.

Both INGOs and their domestic counterparts are strongly involved in the promotion of sustainable livelihoods, particularly the promotion of non-timber forest product (NTFP) alternatives to logging. These activities, and the promotion of SFM and the extension of protected areas have negative implications for logging tax revenues, but not necessarily for 
total revenues, depending on the nature of NTFP, and potential new sources of revenue for protected areas from REDD+.

The final set of stakeholders are the forestry research community. Forestry research has traditionally been seen as a branch of the natural sciences, and so has had little to say on these outcomes. The emergence of 'social forestry', particularly in Ghana, has the potential to change this.

Having examined how the interests of stakeholders may be affected by different REDD+ scenarios, and having linked their behaviours to outcomes with respect to forest taxation, the final section of this study completes the loop by looking at policy options in each country. The key questions are: what 'forms' of REDD+ implementation would be most likely to lead to better forest tax outcomes; which stakeholders are best placed to deliver these policies; and how can they be incentivised to do so?

\subsection{REDD+ scenarios, forest tax outcomes and policy options in each country}

\subsubsection{REDD+ scenarios and forest tax outcomes}

Table 14 relates REDD+ scenarios (vertical) to forest tax outcomes (horizontal). In the preceding sections, we have examined the different stakeholders with respect to REDD+ and forest taxation in each of our case study countries, including, most recently, how the activities and behaviours of these actors could affect forest tax outcomes. Table 14 summarises and codifies these analyses. A 'score' is given in the final column. Positive impacts score 1 , negative impacts -1 , neutral impacts 0 , and uncertain impacts 0.5 . No pretence to precision is made. Rather the aim is to give an indicative sense of which REDD+ features are quite likely to have positive effects (very high scores), which would probably be negative (very low scores) and which are currently unclear, but would depend on the detail of implementation.

Broadly, our scenarios all fall into one of these categories. The high scoring set (5+) are: governance conditionality; effective MRV; equitable participation and benefit sharing. As governance is key to outcomes in the forestry sector, it seems likely that effective conditionality that leads to improved sector governance as a result of REDD+ would also improve outcomes in forest taxation.

Table 14 Potential impact of REDD+ scenarios on forest tax outcomes

\begin{tabular}{|c|c|c|c|c|c|c|c|}
\hline $\begin{array}{l}\text { Forest tax } \\
\text { outcomes }\end{array}$ & $\begin{array}{l}\text { Revenue } \\
\text { raising } \\
\text { potential }\end{array}$ & SFM & $\begin{array}{l}\text { Equitable } \\
\text { sharing of } \\
\text { forest taxes }\end{array}$ & $\begin{array}{l}\text { Promotion of } \\
\text { domestic } \\
\text { industries }\end{array}$ & $\begin{array}{l}\text { Promotion of } \\
\text { sustainable } \\
\text { livelihoods }\end{array}$ & $\begin{array}{l}\text { Good } \\
\text { governance }\end{array}$ & 'Score' \\
\hline \multicolumn{8}{|l|}{ REDD+ scenarios } \\
\hline $\begin{array}{l}\text { Governance } \\
\text { conditionality }\end{array}$ & $\sqrt{ }$ & $\sqrt{ }$ & $\sqrt{ }$ & - & $\sqrt{ }$ & $\sqrt{ }$ & 5 \\
\hline $\begin{array}{l}\text { High REDD+ } \\
\text { finance (national) }\end{array}$ & $?$ & $\sqrt{ }$ & - & $?$ & $?$ & $\sqrt{ }$ & 3.5 \\
\hline $\begin{array}{l}\text { High relative } \\
\text { REDD+ finance } \\
\text { (per unit) }\end{array}$ & $\mathrm{X}$ & $\sqrt{ }$ & $?$ & $?$ & $\sqrt{ }$ & $\sqrt{ }$ & 3.5 \\
\hline $\begin{array}{l}\text { Extensive } \\
\text { coverage }\end{array}$ & $\mathrm{X}$ & $\sqrt{ }$ & $?$ & $\mathrm{X}$ & $?$ & $\sqrt{ }$ & 1 \\
\hline Effective MRV & $\sqrt{ }$ & $\sqrt{ }$ & $\sqrt{ }$ & $\sqrt{ }$ & $\sqrt{ }$ & $\sqrt{ }$ & 6 \\
\hline High participation & $\sqrt{ }$ & $\sqrt{ }$ & $\sqrt{ }$ & - & $\sqrt{ }$ & $\sqrt{ }$ & 5 \\
\hline $\begin{array}{l}\text { Equitable sharing } \\
\text { of benefits }\end{array}$ & $\sqrt{ }$ & $\sqrt{ }$ & $\sqrt{ }$ & - & $\sqrt{ }$ & $\sqrt{ }$ & 5 \\
\hline $\begin{array}{l}\text { National } \\
\text { implementation }\end{array}$ & $?$ & $?$ & $?$ & $?$ & $?$ & $?$ & 3 \\
\hline $\begin{array}{l}\text { Sector } \\
\text { implementation }\end{array}$ & $?$ & $?$ & $?$ & $?$ & $?$ & $?$ & 3 \\
\hline
\end{tabular}




\begin{tabular}{|l|l|l|l|l|l|l|l|}
\hline $\begin{array}{l}\text { Use of existing } \\
\text { channels of } \\
\text { disbursal }\end{array}$ & X & X & X & X & X & X & -6 \\
\hline
\end{tabular}

Effective MRV is the most obviously positive feature of REDD+. A key obstacle to all forest tax objectives is the prevalence of illegal forest activities. As well as reducing illegal logging in environmentally protected areas, an effective MRV system for REDD+ could be adapted and extended to commercial forests.

The argument in favour of high participation and equitable sharing of the benefits of REDD+ programmes is subtler. Many poor outcomes in the forest sector involve local communities, either directly, or indirectly by 'turning a blind eye'. The best potential observers of what is going on in many forests, particularly in remote areas, are local communities. To fulfil this potential, however, they would need to be compensated for any losses of income associated with IFAs. The careful distribution of REDD+ payments to ensure correct incentives creates an opportunity to do this. The chances of benefit sharing systems being designed in this way would be increased if these groups were fully involved in REDD+.

The scenario that comes out as clearly negative (-6) is the use of existing channels of forest finance disbursal for REDD+ finance. In each case study, these funds are often diverted at various points. Channelling REDD+ funds through the same channels would be unlikely to lead to positive impacts on forest tax outcomes, therefore. The alternative is to establish new channels, and potentially reform the way forest taxes are disbursed to align with this new system.

The impacts of the remaining scenarios are less clear. For both national/local or sector/nonsector implementation, the impact would largely depend on the relative competence and integrity of these entities, with those most supportive of good governance creating the most positive impacts on forest tax outcomes. For our indeterminate scenarios in general, however, by far the most important factors are the two REDD+ finance scenarios and the extent of REDD+ coverage.

The key determinant is the net effect on private sector actors. The private sector (formal and informal) is the main driver of deforestation. The formal sector is also the main source of forest tax revenues, the principal potential driver of local industrial development, and is central to good governance in the forest sector. Improving forest tax outcomes is impossible without private sector engagement. It is clear, therefore, that the achievement of positive outcomes for both REDD+ and forest taxation requires behaviour change on the part of private sector stakeholders. The unavoidable conclusion is that they should be incentivised appropriately, with a share of REDD+ finance used to offset any commercial losses. Crucially, this would also have to include informal chainsaw operators.

To maintain incentives vis-à-vis other land uses, the value of REDD+ would have to be linked to commodity prices. Whether this is a 'price worth paying', particularly when opportunity costs are high due to commercially attractive alternative land uses, is an important area for future research.

To summarise, our preferred mix of REDD+ scenarios for forest tax outcomes would be: effective governance conditionality; high REDD+ finance (national); high REDD+ finance (relative); extensive coverage; effective MRV; high participation; equitable sharing of benefits (including to affected private stakeholders); and new channels of disbursal. 


\subsubsection{Current policy debates in Cameroon, Ghana and Sierra Leone}

Decisions on the first three desirable features of REDD+ implementation will be taken at the supranational level. For significant REDD+ finance to have positive effects, it must be preceded and accompanied by major governance reform in forestry sectors. If not, REDD+ will fail to achieve its objectives, and risks making current governance problems worse. Second, unless and until there is a functioning global carbon market, REDD+ finance will be overwhelmingly provided by donors. How much they choose to provide will therefore determine the total amount of funding that is available. How donors and implementing agencies (e.g. UN-REDD) then choose to allocate funding between countries will determine how much annual finance each country receives. How these agencies then structure REDD+ programmes will determine how much REDD+ finance is provided per unit of carbon.

The lack of a global carbon market suggests that some version of the opportunity cost funding method will be used, rather than relying on carbon market prices. While preferable to current carbon prices, current approaches to opportunity cost systematically underestimate what is likely to be required, and do not take sufficient account of non-economic constraints in many potential REDD+ countries, particularly in sub-Saharan Africa (Gregerson et al. 2010). Although these difficulties are significant they do not appear to be insurmountable, particularly if REDD+ opportunity costs are estimated carefully and realistically, and governance reforms designed to address the main non-economic issues.

Domestically, decisions have to be taken on the remaining issues: high/low participation; equitable/inequitable sharing of benefits; extensive/limited coverage; effective/ineffective $\mathrm{MRV}$; new/existing channels of disbursal. In the remainder of this section, we consider policy debates in each country in these areas, and identify the actors with the greatest influence in these debates.

\section{a) Cameroon}

High vs. low participation of stakeholders in REDD+ planning and design While there is an ongoing participatory and consultative platform nationally and throughout the regions, actual consultation and participation is very limited and restricted to a narrow official agenda. Engagement to date has largely entailed information sharing and capacity building for national stakeholders as well as collecting feedback with regards to local problems, needs and perspectives.

Going forward, Cameroon needs to strengthen the coordination of the inter-ministerial agencies in charge of forests, the environment and REDD+ activities, in addition to the efforts of the Consultation Circle of Partners of MINEPDED and MINFOF, a mainly donor-led platform. Roles and responsibilities between MINEPDED and MINFOF and key ministries need to be clearly defined. A promising option would be to strengthen existing initiatives such as the REDD+ and Climate Change Platform, made up of almost 60 CSOs, organised into 19 civil society networks (REFACOF, RFC, and ROS4C 2011), which was created in July 2011 with the aim of coordinating and channelling members' contributions to REDD+ policy mainly through the Technical Secretariat (TS) within MINEPDED.

Intergovernmental organisations are the most prominent actors in the REDD+ arena, followed by international NGOs and state agencies, domestic NGOs, donor agencies, domestic businesses, and national research institutions. Multinational businesses are the least prominent. Local universities, community groups and local authorities have so far not been very engaged with REDD+. Other relevant state agencies, such as those in charge of agriculture, mining, land tenure and economic planning, have little engagement and influence over REDD+. 
Equitable sharing of benefits between local stakeholders

The allocation of forest tax revenues is currently 50 per cent for the Central Government, 20 per cent for the Special Equipment and Intercommunal Intervention Fund (FEICOM), 20 per cent for municipal councils and 10 per cent for forest communities. The governance, transparency, effectiveness, fairness and social justice shortcomings of this allocation have been well documented. The question is how, if at all, any REDD+ benefit sharing scheme will relate to this, especially given other existing gaps such as the lack of comprehensive laws or policies clarifying the rights of indigenous peoples. ${ }^{10}$

More broadly, an analysis of existing rights to natural and forest resources, and their potential impacts on a mechanism for equitable benefit sharing, will be conducted under the leadership of the MINEPDED agencies. Existing mechanisms with options for benefit sharing, such as the Annual Forest Fee, with the allocation between the Central Government and decentralised entities outlined above, are being considered for their appropriateness with relation to REDD+.

The current dominance of national stakeholders, such as the Ministry of Finance and FEICOM, as well as mayors and local elites, may need to be reviewed to ensure fair benefit sharing under REDD+.

\section{Extensive vs. limited coverage}

The TS within MINEPDED has established criteria for REDD+ pilot initiatives in Cameroon over a clearly defined land area. While many REDD+ initiatives have been proposed, they are focused on capacity building, research and information exchange and do not fulfil the criteria laid down by the REDD+ Steering Committee and therefore do not yet qualify as 'pilots'. The TS aims to enhance understanding of the direct and indirect causes of deforestation and forest degradation in these areas, leading to suggestions for ways to slow down or reverse this tendency. But these ideas and initiatives are still mainly donor initiated and led, with the national agencies still in their infancy, or lacking the technical and financial resources and/or political will to initiate such initiatives and reforms.

Given the politically contested nature of forest tax governance, benefits sharing and reform in Cameroon, it seems likely that questions of the likely coverage of REDD+ will be controversial. As the REDD+ agenda has been driven primarily by the donor community to date, and as this is likely to continue for the foreseeable future, their influence on this question is likely to be significant. This is likely to occur in a variety of ways, such as influencing government policy and strategy development, initiating and supporting pilot projects, and providing financial and other support to empower and build the capacities of fledgling national stakeholders such as central government agencies, civil society organisations and community groups. The persistent governance and distributional issues documented in the forest tax system elsewhere are likely to be repeated under REDD+, unless the unlikely but much needed drastic reforms and implementation are initiated.

\section{Effective MRV}

There is as yet no domestic MRV system in place. The MRV unit within the TS is responsible for constructing the national (carbon stocks) reference scenario and the MRV system. The National Observatory on Climate Change (ONACC), on the other hand, will participate in monitoring carbon stocks and play a role in the management and approval of REDD+ projects and programmes, with SGS likely to be the independent observer and monitoring agency.

\footnotetext{
10 While no benefit-sharing mechanism for REDD+ currently exists, the Centre pour l'Environnement et le Développement (CED) has piloted a payment for environmental services (PES) programme, and lessons are being learned. The PES initiative is the outcome of a partnership between the CED, BioClimate Research and Development (BioClimate) and the Rainforest Foundation UK, and is part of the first round of initiatives to be financed out of the US $\$ 100$ million Congo Basin Forest Fund (CBFF), a multi-donor fund set up in 2008 to protect forests in the Congo Basin.
} 
As in other areas, Cameroon has gained useful experiences from current or past REDD+ related pilots. These initiatives are implementing pilot projects with regard to forest monitoring/carbon mapping, including the provision and free access of new and archival satellite images. The regional FAO-COMIFAC-CBFF MRV project (COMIFAC - Commission of Central African Forests), for example, supports Congo Basin countries in developing national forest-monitoring systems and standardised approaches to carbon stock estimation, in line with Intergovernmental Panel on Climate Change (IPCC) guidelines. It is still necessary to review the existing data and methods, identifying gaps, and building capacities to develop protocols and systems adapted to the context of Cameroon. And the roles of the TS and ONACC require further clarification as they potentially overlap.

Additional capacity building is still needed to strengthen MRV capacity to develop sound reference scenarios to monitor and track carbon emissions from deforestation. Current experience still points to continued dependence on foreign support and expertise for the foreseeable future.

New channels of finance disbursal

Legal forest revenues are distributed through the Ministry of Finance, FEICOM, municipal councils and the communities. The question is whether REDD+ finance will be disbursed through these channels, or through others, established specifically for this purpose.

To date, the majority of REDD+ financing has come through bilateral and multilateral channels to support specific projects. While Cameroon supports carbon markets as a source of REDD+ finance, this does not look likely for the foreseeable future. Given the likely continued dependence on sub-national donor funded pilot projects, it is likely that most REDD+ funding will go directly to projects rather than being transferred to government. If so, this could suggest a higher prospect of benefits reaching local communities than under the current forest tax benefit sharing systems.

Project level financing would not automatically enhance equitable benefit sharing at the local levels, however, as those could still be hijacked by local elites or lower levels of state bureaucracy; nor ensure effective implementation of the projects, given other weak governance issues and limited local absorptive capacity. Finally, a focus on project finance may generate hostility and low support from powerful central government agencies such as ONACC and the TS (under MINEPDED and the Ministry of Finance), which will wish to control foreign funding coming into the country.

\section{b) Ghana}

\section{High participation of stakeholders}

Stakeholder participation is already significant in the planning and design of REDD+ in Ghana. A key process was the development of the REDD+ safeguard instruments including: a Strategic Environmental and Social Assessment (SESA); Environmental and Social Management Framework (ESMF) $;{ }^{11}$ and a Resettlement Policy Framework (RPF). ${ }^{12}$

11 The purpose of the ESMF is to: establish clear procedures and methodologies for the environmental and social assessment, review, approval and implementation of interventions to be financed under the project; specify appropriate roles and responsibilities, and outline the necessary reporting procedures, for managing and monitoring environmental and social concerns related to project interventions; and determine the training, capacity building and technical assistance needed to successfully implement the provisions of the ESMF. The ESMF for REDD+ has been prepared to be consistent with the already drafted ESMF for the other World Bank financed forest management initiative, the Forestry Improvement Programme (FIP) and other related programmes such as the World Bank's Dedicated Grant Mechanism (DGM) and the United Nations Framework Convention on Climate Change (UNFCCC). This will ultimately feed into a sector Safeguards Information System.

12 The preparation of a Resettlement Policy Framework (RPF) is a requirement for projects that may entail involuntary resettlement, acquisition of land, impact on livelihoods, or restricted access to natural resources under the World Bank 
Consultative workshops were undertaken to inform the finalisation of these frameworks and the workshops were well attended by CSOs in Ghana.

The consultative processes for the development of the REDD+ dispute resolution and benefit sharing mechanism involved the active participation of civil society groups. ${ }^{13}$ Civil society groups are also well represented on the National REDD+ Working Group and the various sub working groups. In addition, several CSOs are engaged in initiatives which are complementary to REDD+. For example, the Conservation Alliance and the Nature Conservation Research Centre (NCRC-Ghana) are involved in analytical work and stakeholder consultations/training on climate-smart cocoa production systems, and the International Union for Conservation of Nature (IUCN) has been implementing a forest landscape restoration project, focused on the issue of benefit sharing.

The main issue in the REDD+ participation debate has been how to ensure that those who represent local communities and civil society are responsive and accountable. In practice, the Forestry Commission remains the most influential actor in this regard.

\section{Equitable sharing of benefits}

This is perhaps the most debated aspect of REDD+ in Ghana, not least as it is linked to issues such as land tenure and incentives with respect to illegal chainsaw milling. The IUCN, under its pro-poor REDD+ project, has stimulated a lot of discussion on benefit sharing. The Forestry Research Institute of Ghana was also commissioned recently to prepare options for benefit sharing under REDD+. A number of individual studies have also addressed aspects of benefit sharing which are very relevant to REDD+.

The Ministry of Lands and Natural Resources has engaged a consultant to collate all the relevant lessons on the subject and present a synthesis for a national stakeholder consultation to build a national consensus. This was a critical component of the Ghana REDD+ Readiness Package submitted to the World Bank's Forest Carbon Partnership Facility (FCPF) in March 2016 as part of the overall strategy. The Forestry Commission, traditional authorities and civil society actors remain important actors in determining the content of the final benefit sharing arrangement. Notably, the Ghana legal working group facilitated by ClientEarth (an informal coalition of civil society actors interested in improving the legal framework for good forest governance), the IUCN, Forest Watch Ghana, the National House of Chiefs and the REDD+ secretariat of the FC are expected to be key influential actors.

In Ghana, all naturally occurring trees are vested in the state. However, with respect to farms, no timber rights can be granted without the authorisation of the individual, group or owners concerned. For lands with private forest plantations or with any timber grown or owned by any individual or group, no timber rights can be granted. These arrangements have implications for any benefit sharing under REDD+. First, they define the boundaries of which eligible actors should benefit from any REDD+ project, depending on the land tenure system that prevails. Second, the constitutional formula on benefit sharing from natural forests that allocates specific proportions to managers, landowners and local government brings clarity and confusion at the same time. For instance, while it is clear who would be allocated benefits, the retention of 50 per cent of revenue by the FC as 'management cost' has been questioned, as farmers are also viewed as 'managers' in off-reserve areas. The third and perhaps most complicated issue, is how carbon rights will be defined in reference to tree or land ownership rights. These issues remain unanswered.

safeguard policy on involuntary resettlement. The RPF will provide project stakeholders with information on how to address compensation issues as related to affected properties/livelihoods, including land and income generation activities during project implementation.

13 IUCN, Tropenbos International, Civic Response, Rainforest Alliance, Abantu for Development, National Forest Forum. 


\section{Extensive coverage}

While Ghana's protected forests are primary targets for REDD+ projects, programmes will extend beyond these areas as the hot spots of deforestation also cover off-reserve areas. For example, the current Emissions Reduction Programme covers the forest-cocoa mosaic landscape. There are no policy restrictions yet on the extent of coverage. The Forestry Commission has a mandate to manage and develop forest resources. As the facilitator of REDD+ programmes, it remains an important actor, and will be the key stakeholder in determining the extent of REDD+ coverage.

\section{MRV}

The reference levels for forest emissions, and the GHG measurement approach, has been developed by Indufor OY, ${ }^{14}$ contracted by the Forestry Commission. The design of the MRV system is broadly in line with IPCC good practice guidelines. An internal report, produced for the Forestry Commission, dwells on forests, with guidance relating to other land use systems (which may be relevant for REDD+) remaining unaddressed. Moving forward, it will be important to move beyond current mechanisms for monitoring deforestation to a more robust system that can assist in measuring degradation and forest carbon stocks enhancement.

In addition, an agreement for selective logging in the Emissions Reduction Programme accounting area (Ghana's high forest zone) has been developed. Further work will be undertaken by the Forestry Commission during the additional funding phase of this programme to fill identified gaps in relation to Carbon Stock Enhancement and other elements of degradation (fire, illegal logging etc.). This work will be based on the standard operating procedures developed during the first phase of REDD+.

\section{New channels of finance disbursal}

The channels of distribution of REDD + finance have not been decided, and to a large extent have been discussed in tandem with benefit sharing. If the channels of distribution stay within the boundaries of the current legal regime, the Forestry Commission and leading civil society groups will be key actors. Otherwise, the Ministries of Lands and Natural Resources and Justice and Attorney General, and the Parliament of Ghana, will be important in facilitating any constitutional reforms.

\section{c) Sierra Leone}

\section{High participation of stakeholders}

Although there has been some stakeholder involvement in the RSPB-funded pilot carbon credit project in the Gola Forest, broad-based participation has been limited. Local communities are yet to be reached. Even where consultation has occurred, the results are rarely taken into consideration in policy formulation.

The need to build the capacity of potential participants is an important prerequisite for participation. In this regard, NGOs, civil society groups and policy makers can play crucial roles. These stakeholders are also the agencies who by nature of their work and influence can actually promote high participation of community stakeholders in the REDD+ process. To ensure informed inputs from community stakeholders are captured in REDD+ planning and programme design, validation workshops with contributing community stakeholders should be held prior to concluding any programme design.

\section{Equitable sharing of benefits}

Communities will benefit from carbon credit sales from the Gola Forest project. Whilst forest field officers, researchers and NGOs are of the opinion that the community should have the

14 A consulting firm based in Finland which was contracted to lead the Ghana MRV development project. 
largest share of revenues, the benefit sharing formula allocates just 15 per cent to communities, much lower than the 40 per cent suggested at earlier negotiations.

As the formal owner of protected areas such as Gola, the government is able to dictate revenue shares. Community forests, in contrast, are owned by local communities, traditional authorities and, in some cases, private investors. The 'community' in this context refers to local landowners and traditional authorities (paramount chiefs) who are the custodians of the chiefdom lands. This suggests that the formula agreed for the Gola Forest may not be applicable in community forests, as communities will have more scope to argue for a larger share. If government were to propose a low community share, the country's civil society groups would also advocate on behalf of the community.

Perhaps more significantly, current forestry law makes provision for a higher community share of community forests, which should be applicable if REDD+ coverage is extended to these forests.

\section{Extensive vs. limited coverage}

A full inventory of Sierra Leone's forests remains to be conducted, but there are already protected areas which REDD+ is expected to cover. To further preserve valuable flora and fauna, it has been suggested (based on interviews with conservation NGOs and forest communities in the Western Area forests) that REDD+ should include some community forests. Discussions with NPAA and Forestry Division officials suggest they support this move, both as a means of reducing deforestation and of potentially raising additional revenues from REDD+ finance. The position of the commercial unit of the Forestry Division, which could see revenues from forestry taxation fall, is less clear.

The extent of community forest coverage will be the key issue, and the most important stakeholders in determining policy in this area are the Ministry of Agriculture, Forests and Food Security (MAFFS), the National Protected Area Authority (NPAA), the Environmental Protection Agency (EPA) and, particularly, the Office of the President. To ensure their support, sufficient compensation to landowners, traditional authorities and local government for use of their community forests will be needed.

How local communities are affected will also be key in determining their positions. Discussions with senior government officials suggest they understand this, and have proposed that communities are compensated if they support changing the classification of forests to national reserves under REDD+ programmes. The nature and scale of this compensation, relative to what is currently received from both formal and informal community forest sources, will be crucial in determining outcomes.

\section{Effective MRV}

At present, MRV activity in Sierra Leone is dominated by external actors, making the process slow and expensive, as well as raising issues of legitimacy. To ensure the MRV system is effective, efficient and legitimate, it should be owned and implemented domestically, whilst remaining compatible with the internationally agreed standards. If external MRVs are preceded by internal MRVs, the former will be less demanding and forecasting of REDD+ revenues quicker. Establishing internal MRV should make reporting easier, in the same way that internal audits help prepare institutions for external audits. While such a mechanism has yet to be set up, discussions with a senior official from the pilot carbon credit project have suggested this is imminent, and that a research department under the pilot project is being enhanced to conduct MRV internally. An interview with a key domestic CSO suggested the need for a strong monitoring and evaluation mechanism for REDD+ to ensure it is well implemented. 
Any policy on national MRV should therefore include the setting up of an institutional MRV infrastructure, a clear mandate and the establishment of national capacity to meet REDD+ requirements.

\section{New channels of finance disbursal}

Forest tax revenues collected by the National Revenue Authority (NRA) are ultimately held by the central bank. Other fees collected by the Forestry Division are retained in their accounts. The government also supports forest activities by transferring revenues to MAFFS. Part of the government consolidated revenue fund provided to the NPAA (which leads the REDD+ implementation) is disbursed directly into their departmental accounts. Whilst the current disbursal mechanism for government stakeholders may be retained, that for traditional authorities, landowners and communities needs to be reformed to ensure effectiveness and transparency, but also to ensure the monies reach the intended community beneficiaries.

Existing channels for disbursal consist of direct payments of cash to traditional authorities and local landowners. The establishment of accounts for beneficiaries and direct disbursement into such accounts was suggested by some community leaders in the Western Area as a way forward. Some community heads, private companies and forest CSOs also suggest that REDD+ resources should be deposited into community bank accounts for sustainable community development purposes.

The Ministry of Finance and Economic Development, private timber companies and MAFFS are critical stakeholders in reforming the disbursal channels. MAFFs is the supervisory ministry for NPAA (which leads the REDD+ implementation) and also has the policy lead role in agriculture and forestry-related matters. MAFFS can recommend to the Ministry of Finance and Economic Development (MOFED) and the central bank that departmental accounts should be established at the government banks and then bank accounts set up at community/rural banks to cater for people in forest communities.

\section{Concluding remarks}

The research summarised in this paper has explored the impacts that REDD+ implementation could have on existing forest tax systems in three countries, and how policy could positively influence this. An important finding is that many of the most important decisions that will determine the impact of REDD+ remain open, so that a real window of opportunity exists for influence.

If this opportunity is not taken, the risk is that REDD+ ends up being shaped by what is easy and feasible, rather than what is necessary and desirable. The overall level of REDD+ finance, and how it is valued in terms of carbon stocks, is a very good example. Rather than being driven by a careful assessment of what finance is needed - taking full account of the cost of vital governance reforms and the need to settle core issues such as land rights and livelihoods - the risk is that both the level and value of REDD+ will be driven by what can be pieced together from a range of donor sources. As has been analysed here, it is highly unlikely that such a REDD+ framework will achieve its goals, and it may even make existing problems in forestry sectors, including with respect to taxation, worse not better.

This need not happen. If designed and implemented with care and sufficient resources, REDD+ has the potential to be a catalyst for positive change in forest governance and forest taxation. There is no shortage of research detailing what is required for this to be the case, and it is hoped this research will also make a positive contribution in this regard. What is needed now, at both the international and national levels, is the political will to deliver, and the financial resources to back this up. 


\section{References}

Acemoglu, D. and Robinson, J.A. (2001) 'A Theory of Political Transitions', American Economic Review 91:4: 938-963

African Women's Network for Community Management of Forests, Community Forestry Network, and Network of Cameroonian Civil Society Organizations on Climate Change (REFACOF, RFC, and ROS4C) (2011) Final Communiqué of the National Platform on REDD+ and Climate Change, Yaoundé, Cameroon

Amanor, K. and Brown, D. (2003) Making Environmental Management More Responsive to Local Needs: Decentralisation and Evidence-Based Policy in Ghana, London: Overseas Development Institute (ODI)

Birikorang, G., Okai, F., Asenso-Okyere, K., Afrane, S., and Robinson, G. (2001) Ghana Wood Industry and Log Export Ban Study, London: Department for International Development (DFID)

Brown, O. and Crawford, A. (2012) Conservation and Peace Building in Sierra Leone, Canada: International Institute for Sustainable Development (IISD)

De Groot, R., Wilson, M. and Boumans, R. (2002) 'A Typology for the Classification, Description and Valuation of Ecosystem Functions, Goods and Services', Ecological Economics 41:393-408

FAO (2011) State of the World's Forests 2011, Rome: FAO

FAO (2010a) Global Forest Resources Assessment Country Report, Ghana, FRA 2010/077, Rome: FAO

FAO (2010b) Global Forest Resources Assessment 2010: Country Report, Sierra Leone, FRA 2010/189, Rome: FAO

FAO (2004) Trade and Sustainable Forest Management - Impact and Interactions, Main Analytic Study of GCP/INT/775/JPN, Rome: FAO

FAO/UNDP (2011) Sierra Leone Forest Information Data, http://rainforests.mongabay.com/deforestation/2000/Sierra_Leone.htm

Forestry Commission (2008) Annual Report, Accra

Fuller, D.O. (2006) 'Tropical Forest Monitoring and Remote Sensing: A New Era of Transparency in Forest Governance?', Singapore Journal of Tropical Forestry 27.1: 15-29

Gehring, T. and Oberthür, S. (2009) 'The Causal Mechanisms of Interaction Between International Institutions', European Journal of International Relations 15(1): 125-156

Ghana Forestry Commission (GFC) (2010) Readiness Preparation Proposal (R-PP), Ghana, Final Document

Gregersen, H., El Lakany, H., Karsenty, A. and White, A. (2010) Does the Opportunity Cost Approach Indicate the Real Cost of REDD+? Rights and Realities of Paying for REDD+, Washington DC: Rights and Resources Initiative 
Gupta, J. (2012) ‘Glocal Forest and REDD+ Governance: Win-Win or Lose-Lose?’, Current Opinion in Environmental Sustainability 4.6: 620-627

Haas, P.M. (1992) 'Introduction: Epistemic Communities and International Policy Coordination', International Organization 46(1): 1-35

Hansen, C.P. and Lund, J.F. (2011) 'The Political Economy of Timber Taxation: The Case of Ghana', Forest Policy and Economics 13.8: 630-641

Hawthorne W.D. and Abu-Juam, M. (1995) Forestry Protection in Ghana, Forest Conservation Series No. 14, IUCN

IPCC (2007) Fourth Assessment Report of the Intergovernmental Panel on Climate Change, Intergovernmental Panel on Climate Change (IPCC), Geneva

Kotey, E.N.A., Francois, J., Owusu, J.G.K., Yeboah, R., Amanor, K.S. and Antwi, L. (1998) Falling into Place, Policy that Works for Forests and People Series No. 4, London: International Institute for Environment and Development

Krasner, S.D. (ed.) (1983) International Regimes, Ithaca, NY: Cornell University Press

La Porta, R., Lopez-de-Silanes, F., Shleifer, A. and Vishny, R.W. (1998) 'Law and Finance', Journal of Political Economy 106(6): 1113-1155

Lee, A. and Schultz, K.A. (2011) 'Comparing British and French Colonial Legacies: A Discontinuity Analysis of Cameroon', paper presented at the APSA 2011 Annual Meeting, Seattle

Lopez, R., and Galinato, G. (2005) 'Deforestation and Forest-Induced Carbon Dioxide Emissions in Tropical Countries: How Do Governance and Trade Openness Affect the Forest-Income Relationship?', The Journal of Environment and Development 14.1: 73-100

MAFFS (2014) Agricultural Sector Review Volume III, Sector Report, Institution and Human Resources Development, Sierra Leone: MAFFS

Marfo, E. (2006) 'The Role of Actor Empowerment in Natural Resource Management. A Case of Forest Conflicts in Ghana', PhD thesis, Wageningen University, Netherlands

Marfo, E., Acheampong, E. and Opuni-Frimpong, E. (2012) 'Fractured Tenure, Unaccountable Authority, and Benefit Capture: Constraints to Improving Community Benefits Under Climate Change Mitigation Schemes in Ghana', Conservation and Society 10(2): 161172

Mkandawire, T. (2010) 'On Tax Efforts and Colonial Heritage in Africa', The Journal of Development Studies 46(10): 1647-1669

REDD+ Technical Secretariat, Cameroon (undated) Cameroon's Forest Investment Plan, https://www.climateinvestmentfunds.org/sites/default/files/meetingdocuments/cameroons_forest_ip.pdf

Seymour, F. (2011) 'Forests and Food Security: What We Know and Need to Know', Forests News Blog, 20 April, http://blog.cifor.org/2592/forests-and-food-security-what-we-know-andneed-to-know\#.VBwHTxaCN64 
Timber Industry Development Division (TIDD) (2014) Report on Export of Wood Products, December 2014, Ghana Forestry Commission

UNEP WCM (2007) UN Environment Programme World Conservation Monitoring Centre (UNEP WCM) database, http://www.unep-wcmc.org

USDA Forest Service (2000) Overview of the Western Peninsular Forest Reserve (WPFRP)

Vincent, J.R., Gibson, C.C. and Boscolo, M. (2005) The Politics and Economics of Timber Reforms in Cameroon, Washington, DC: World Bank Institute/World Bank 